\title{
Journal of Language Education and Research
}

\author{
Research Article
}

\section{A Content Analysis of National and International Graduate Theses on Children's Literature}

\author{
Sevil Hasırcı Aksoy ${ }^{*} \quad$ Aslıhan Küçükavşar ${ }^{* *}$
}

\section{ARTICLE INFO}

Received 11.01.2021

Revised form 04.04.2021

Accepted 11.04.2021

Doi: $10.31464 /$ jlere. 831792

Keywords:

Children's literature

National theses

International theses

Content analysis

\begin{abstract}
This study aims to investigate and evaluate the national and international graduate theses on "children's literature" according to their graduate levels, publication years, research topics, research questions, purposes, methods and data collection tools. The National Thesis Center database of Council of Higher Education was used to access national theses, and the ProQuest database to access international theses. Scanning of theses was limited to those made between 2010-2019. Document analysis was used utilizing the concepts related to children's literature, and then content analysis was used to analyze the data obtained by means of the form developed by the researchers. It was revealed that female researchers had more studies, national and international theses differed in terms of graduatelevel and year, qualitative design was more preferred in both national and international theses. Prevalent research topics were the function of children's literature in national theses and the ideology in children's literature in international theses.
\end{abstract}

Acknowledgments

Statement of Publication Ethics

Authors' Contribution Rate

Conflict of Interest
The authors accept the responsibility of this article and all the terms of the journal.

The authors hereby declare that they have not used any sources other than those listed in the references. The authors further declare that they have not submitted this article at any other journal for publication.

The authors equally contributed for the article.

The authors declare that there is no conflict of interest.

\footnotetext{
* Assist. Prof. Dr., ORCID ID: https://orcid.org/0000-0003-1041-7558, Gaziantep University, Department of Turkish and Social Sciences Education, sevilhasirci@gmail.com

** Assist. Prof. Dr., ORCID ID: https://orcid.org/0000-0002-7827-7638, Abant İzzet Baysal University, Department of Turkish and Social Sciences Education, aavsar06@gmail.com

*** This study is the expanded version of the paper presented at the 10th International Turkish Education-Teaching Congress (28-30 September 2017).
} 


\section{Introduction}

As it is important to have a deep understanding of the nature of children's world, child's sensitivity and reality, and reflect them into literary products. For this reason, children's literature needs to be considered with a particular importance and priority. This particular type of literature, which has a literary value and deals with children's realities in a sensitive way, can give children love and habit of reading and which gives them an identity of a qualified reader, covers literary products for children between the ages of 4-12 (Dilidüzgün, 2004: 18). It is necessary to put emphasis on children's literature in order to introduce children to good quality books and make them comprehend features of literature and language with an intuitive sense. Therefore, products for children's literature are expected to present children with good quality texts and to build a reading culture over time (Sever, 2003: 11).

“Children's literature is, principally, a form of literature. It is the most sophisticated form of writing within literature in terms of its literary value. It is a new genre in literature that can attract readers of all ages with its language, expression and form" (Şirin, 2000: 10). All principles related to the formation of literature are also necessary for children's literature. But it differs from adult literature. Because children's books are written for a different audience, with different skills, different needs, and different ways of reading (Hunt, 2005: 3). That's why, what is expected from children's literature is not to perceive children as objects to be shaped but respect them as adults and express their concerns and experiences, and that can function as a bridge to encourage self-expression will serve a significant purpose (Neydim, 2003: 94). Books with a good quality are needed to fulfill this function for children. Opportunities based on recognizing and understanding messages of literary texts and pictures should be provided for children to apply and test their cognitive and affective behaviors (Sever, 2003: 11-12). While doing this, it should also be of a quality that creates the child's reading enjoyment, literary and artistic preferences, gives the child the opportunity to imagine, be inspired, and vicarious experiences, gives the child the ability to reason, and improves the child's understanding and empathy sense (Lynch-Brown \& Tomlinson, 1999: 3-4). And also, children's books should be appropriate to the number of words in the child's language vocabulary and should have sentence structures and forms of expression that they can comprehend (Kantarcioğlu, 1991: 13). Moreover, books should include a scientific perspective regarding children's ability to synthesize in terms of perception and cognition. This is because children's literature plays an important role in introducing them to writing, in developing perception and cognition, and in being literate. All these indicate that children's literature should be investigated from different aspects. In this context, it is necessary to conduct content-oriented studies on theses in the field of children's literature in the related literature.

Books for children and young adults as important instruments for literature education can raise an awareness of literature. In other words, children's books with good quality are forms of a transitional literature which gives children initial opportunities to ask questions (Dilidüzgün, 2003). Thus, literary products for children and studies on children's 
literature are of great importance as they provide a significant reality for children by giving them tasks of implementation, self-evaluation and perception-cognition.

\section{Literature review}

There is a growing number of studies on education as a result of the developments in the field. With this regard, it becomes more important to question quality of these studies. A number of academic studies have been investigated in the field of Turkish education from different viewpoints: Master's and doctoral theses in the field of teaching Turkish, papers at international scientific conferences, articles (Sevim \& İşcan, 2012; Sevim \& Özdemir Erem, 2012; Şahin, Kana \& Arrivaloğlu, 2013; Arrivaloğlu, Şahin \& Göktaş, 2013; Aktaş \& Uzuner Yurt, 2015; Bozkurt \& Uzun, 2015; Boyacı \& Demirkol, 2018; Turan, Sevim \& Tunagür, 2018), methods in language teaching (Eski, 2019), listening skill (Doğan \& Özçakmak, 2014), e-books (Alpkıray \& Samur, 2018), critical reading (Çam Aktaş, 2015), visual literacy (Tanrıverdi \& Apak, 2013), speaking skill (Potur \& Y1ldız, 2016; Alver \& Taştemir, 2017), media literacy (Erdem, 2018), reading skill (Akaydın \& Çeçen, 2015; Ceran, Aydın \& Onarıcıŏlu, 2018; Değirmenci Gündoğmuş, 2018; Özdemir, 2018; Yıldız, Çoban Sural \& Boz, 2019), poetry (Şeref, 2019), Turkish language and literature education (Veyis, 2020 ), teaching Turkish to foreigners (Büyükikiz, 2014; Biçer, 2017; Küçük \& Kaya, 2018; Türkben, 2018) and writing education (Tok \& Potur , 2015).

A number of studies have been conducted on children's literature in Turkey. Gürel and Şimşek (2005) and Altunya (2012) created a bibliography on Turkish children's literature. A total of 230 theses are included in the bibliography on children's literature by Gürel and Şimşek (2005). Altunya (2012) reviewed and analyzed graduate theses between 1974-2011 chronologically. Coşkun, Özçakmak and Balcı (2011) complied 233 graduate theses on children's literature and discussed the trends in teaching Turkish. In that study, Balc1 (2012) classified and evaluated graduate theses (267 theses) on children's literature between 1981-2010 according to their type, preparation period and research topics. Yazic1 (2013) examined 249 theses, accessed from the database of Council of Higher Education (CoHE), in many aspects such as research topic, type of research, and department. Fidan (2019) evaluated graduate theses on children's literature in terms of values education. Balta (2019) investigated 278 theses on children's literature between 2011-2018, and Ertekin and Çamlıbel Çakmak (2019) compiled and reviewed 56 graduate theses on illustrated children's books for preschool children. However, it seems that the studies conducted are limited to national theses without any comparison to international theses. This study is expected to provide a deeper insight for researchers as it reviews both national and international theses.

There is a need to identify the trends (about research topic, research method, data collection tools etc.) in studies on children's literature for researchers who aim to study on children's literature. That's why, the aim of this study is to determine the similarities and differences according to research topics, research designs, data collection tools, etc. between national and international graduate theses about children's literature. In accordance with the main problem, these sub-questions were examined: 
1. What is the distribution of the year of the national and international graduate theses since 2010 ?

2. What is the distribution of the gender of researchers of the national and international graduate theses?

3. What is the distribution of postgraduate level of the national and international graduate theses?

4. What are the research topics of the graduate national and international theses?

5. Which research designs were chosen at national and international graduate theses?

6. Which data collection tools were used at national and international graduate theses?

7. Which study groups/samples were attained at national and international graduate theses?

\section{Methodology}

\section{Research design and publication ethics}

The research design for this study is a descriptive scanning model. The aim of descriptive research is to investigate a phenomenon or situation in detail and to attempt to describe what it is by examining its relationship with other previous phenomena or situations (Karakaya, 2014: 59). Descriptive science involves observation, recording, determining the relationship between cases and making generalizations from unvarying principles (Yıldırım \& Şimşek, 2006). The study was conducted in four stages. (i) Developing a framework for the descriptive analysis: At this stage, a framework for data analysis was developed based on the conceptual framework of the study in order to determine the themes to classify the data. (ii) Processing the data: At this stage, the reviewed data obtained based on the general framework developed in the previous stage was read and organized. (iii) Defining the findings: At this stage, the organized data was defined and listed under appropriate categories. (iv) Interpretation of the findings: At this stage, the defined data were explained and associated. In this study, theses published between 2010 and 2019 accessed through the national database of Council of Higher Education (CoHE) and international database of ProQuest were analyzed in terms of several variables. The most recent thesis included in the study was published in June 2019, which is the limitation of the study. In this process, the authors complied with Research and Publication Ethics.

\section{Data collection and analysis}

The keywords "child", "literature", "children's literature" and "juvenile literature" were used to collect the data. The data were collected within the framework of the following criteria: a) Theses available in CoHE national thesis database and ProQuest database, b) theses related to children's literature, c) theses published between 2010 (01.01.2010) and 2019 (30.06.2019), (d) theses for master and doctoral programs. With these criteria, 220 theses in the national database and 209 theses in the international 
database were accessed. A total of 80 theses were excluded as there were repetitive manuscripts and the language to be included was only English for international theses, which decreased the number from 289 to 209.

Content analysis was utilized for the data analysis. Content analysis can be broken down into the stages of specifying the purposes, identifying the locations of the related data, developing a logical structure, deciding on the categories for coding, quantification and interpretation (Büyüköztürk et al, 2016, 252-255). Firstly, it was ensured that each study included the relevant purpose. Following this, the criteria to follow were specified. With this purpose, similar studies on the content analysis of theses and articles were reviewed together with the forms that were used (Sözbilir, Kutu \& Yaşar, 2012; Kurt \& Erdoğan, 2015).

\section{Procedure}

In the light of the studies mentioned above, a form was developed to cover all the studies on children's literature. This form consists of eleven categories including descriptive information about thesis and researcher's identity, research design / method and research topic (Table 1):

Table 1. Titles for Analysis of National and International Theses

\begin{tabular}{l}
\hline Thesis Title and Number \\
\hline Place of Publication (National, International) \\
\hline Thesis Acceptance Year \\
\hline Gender of the Researcher (male, female) \\
\hline Graduate Level (Master's, Doctoral) \\
\hline Research Design \\
\hline $\begin{array}{l}\text { Data Collection Tool (observation, interview, document analysis, questionnaire, test, scale, passing grade, } \\
\text { other) }\end{array}$ \\
\hline $\begin{array}{l}\text { Study Group/Sample (students, preservice teachers, teachers of Turkish, primary school teachers, printed } \\
\text { materials, other) }\end{array}$ \\
\hline Research Topic
\end{tabular}

After the form was created and a logical structure was developed for the analysis of the theses, the content of each thesis was coded into the form with regard to the categories defined previously. A coding session was held attended by the researchers to ensure validity followed by a subsequent coding in accordance with the defined categories with each researcher responsible for equal set of theses. Then, a second session was held in order to ensure a consistent coding. Each researcher re-coded $20 \%$ of theses chosen randomly. In this process, which was conducted to ensure that the codes were consistent with each other, an internal consistency calculation was made. In the calculations made using the reliability formula of Miles and Huberman (1994), the reliability coefficient was at $90 \%$. The interpretation of the obtained findings through quantification was the final step of the content analysis. 


\section{Results}

\section{Distribution of theses according to gender}

The distribution of the researchers by gender is given in Figure 1. As can be seen in Figure 1, female researchers in both national and international theses constitute more than half of the distribution.

Figure 1. Distribution of National and International Theses by Gender
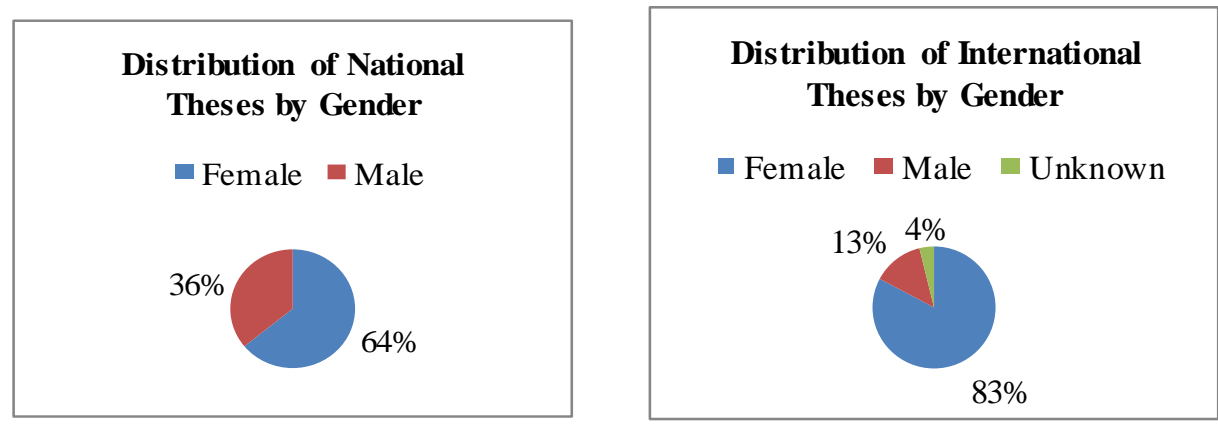

Sixty-four percent of the national theses were conducted by female researchers and $36 \%$ by male researchers. Similarly, the majority of the international theses were conducted by female researchers with a percentage of $83 \%$ while the percentage of male researchers is only $13 \%$. However, information as to the gender of $4 \%$ could not be found. As biographies of the researchers are not included in the manuscripts, the acknowledgement section was reviewed; however, no clues were available. In some cases, such expressions as "wife" or "husband" in acknowledgement sections can provide information. The obtained biographical information was also confirmed on internet. However, gender information was stated as "unknown" in cases where no information was obtained despite an intense search.

\section{Distribution of theses according to publication years}

The distribution of the theses by their publication year is given in Figure 2. National and international theses do not seem to have a balanced distribution from 2010 to 2019:

Figure 2. Distribution of National and International Theses by Publication Years

\begin{tabular}{|c|c|}
\hline 50 & ${ }_{0}^{50}$ \\
\hline $\begin{array}{c}\text { Frequency of National } \\
\text { Theses }\end{array}$ & $\begin{array}{l}\text { Frequency of } \\
\text { International Theses }\end{array}$ \\
\hline " 2010 = $2011=2012$ = $2013=2014$ & - 2010 - $2011=2012 \square 2013=2014$ \\
\hline ॠ $2015 \square 2016 \square 2017 \square 2018 \square 2019$ & $\square 2015 \square 2016 \square 2017 \square 2018 \backsim 2019$ \\
\hline
\end{tabular}

It can be seen in Figure 2 that 2011 was the year when the highest number of studies were conducted (f:36) followed by 2015 (f:29), 2010 and 2012 (f:27), 2014 and 2017 (f:25), 2016 (f:19), 2018 (f:16), 2013 (f:11) and 2019 (f.5) respectively. The reason for why the number of the theses was lowest in 2019 seems to be because the scope of the 
study was limited to theses conducted until June. On the other hand, much less studies seem to have been conducted in 2013 when compared to the other years.

The highest number of international theses were conducted in 2013 (f:33) and 2012 (f:32) followed by 2010 (f:29), 2011 (f:25), 2015 and 2016 (f:24), 2018 (f.20), 2014 (f:14), 2017 (f:5) and 2019 (f.3) respectively. The number of theses was lowest in 2019, like in national theses, as the scope of the study was limited to theses conducted until June. However, only 5 theses were conducted in 2017, which is an indication that researchers conducted the least studies on "children's literature" in that year when compared to other years. Moreover, the number of theses seems to have decreased by $40 \%$ in 2014 regarding the amount in 2013.

\section{Distribution of theses according to graduate levels}

The distribution of theses by graduate levels is given in Figure 3. There seems to be a notable difference between national and international theses regarding their graduate levels:

Figure 3. Distribution of National and International Theses by Graduate Level

\begin{tabular}{|c|c|}
\hline $\begin{array}{c}\text { Graduate Level of } \\
\text { National Theses }\end{array}$ & $\begin{array}{c}\text { Graduate Level of } \\
\text { International Theses }\end{array}$ \\
$\square$ Master's $\square \mathrm{PhD}$ & $18 \%$ \\
\hline$\%$ & Master's $\mathrm{PhD}$ \\
\hline 85 & $82 \%$ \\
\hline
\end{tabular}

While $85 \%$ of national theses are at masters' level, only $15 \%$ of them were conducted at doctoral level. In this sense, there is a clear contrast between national and international theses as $18 \%$ of international theses were at master's level and $82 \%$ were at doctoral level. The national theses on children's literature were mainly master's theses while international theses were mostly doctoral theses.

\section{Distribution of theses according to research design and data collection tools}

According to their philosophies the studies are classified from two perspectives: qualitative and quantitative studies (Büyüköztürk et al, 2016: 12). As the mixed method is a combination of qualitative and quantitative approaches and concepts, three types of research design are considered for classification. The distribution of national and international theses by the research design they adopted is given in Table 2.

Table 2. Research Designs in National and International Theses

\begin{tabular}{|c|c|c|c|c|}
\hline Method & & & Frequency of Studies & $\%$ \\
\hline \multirow{3}{*}{ 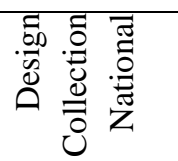 } & \multirow[t]{3}{*}{ Qualitative } & Interview & 7 & $3.19 \%$ \\
\hline & & Observation & - & $0 \%$ \\
\hline & & Content Analysis & 168 & $76.36 \%$ \\
\hline \multirow{3}{*}{ 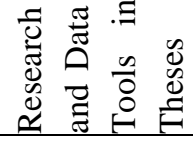 } & \multirow[t]{3}{*}{ Quantitative } & Questionnaire & 8 & $3.64 \%$ \\
\hline & & Scale & - & $0 \%$ \\
\hline & & Test & 4 & $1.82 \%$ \\
\hline
\end{tabular}




\begin{tabular}{|c|c|c|c|c|}
\hline \multirow{3}{*}{+2} & \multirow[t]{3}{*}{ Mixed } & Qualitative-qualitative & 16 & $7.27 \%$ \\
\hline & & Quantitative-quantitative & 3 & $1.36 \%$ \\
\hline & & Qualitative-quantitative & 14 & $6.36 \%$ \\
\hline Total & & & 220 & $100 \%$ \\
\hline \multirow{4}{*}{ 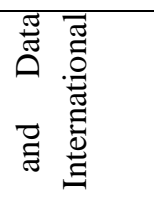 } & \multirow[t]{3}{*}{ Qualitative } & Interview & 4 & $1.91 \%$ \\
\hline & & Observation & - & $0 \%$ \\
\hline & & Content Analysis & 153 & $73.21 \%$ \\
\hline & \multirow[t]{4}{*}{ Quantitative } & Questionnaire & - & $0 \%$ \\
\hline \multirow{3}{*}{ 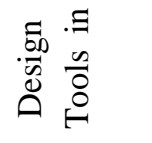 } & & Scale & - & $0 \%$ \\
\hline & & Test & - & $0 \%$ \\
\hline & & Review & 1 & $0.48 \%$ \\
\hline \multirow{3}{*}{ 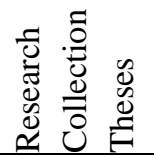 } & \multirow[t]{3}{*}{ Mixed } & Qualitative-qualitative & 24 & $11.49 \%$ \\
\hline & & Quantitative-quantitative & 4 & $1.91 \%$ \\
\hline & & Qualitative-quantitative & 23 & $11.00 \%$ \\
\hline Total & & & 209 & $100 \%$ \\
\hline
\end{tabular}

It is clearly seen that qualitative research design was used dominantly in national theses (f:175, 79.55\%). In line with the qualitative research design, there were frequent literature reviews and the reviewed data was obtained through content analysis. This rate in international theses is $75.12 \%$ and, like in national theses, descriptive analysis was prevalent. On the other hand, no clear statement was available in 36 national and 105 international theses as to which method was used. However, a deeper investigation into these theses showed that they utilized content analysis through document analysis. It is noteworthy that these theses were from departments of literature as the theses from departments of educational sciences had a separate section on methodology and clearly stated the research methods and data collection tools.

Observation as a qualitative research method was not considered as a separate and independent method but integrated into quantitative methods as a mixed method type. Although interviews were utilized independently in some theses (national f:7; international $\mathrm{f}: 4)$, interview was a frequently used qualitative tool in mixed method studies.

Among quantitative research methods, the preferred research design was often experimental design. A total of 12 national theses and 5 international theses made use of experimental research design. The theses that utilized only a questionnaire or only a test as a data collection tool are among only national theses. In international theses, however, these tools were used as a part of mixed method research and were supported with another qualitative or quantitate tool.

Mixed methods research was utilized in national theses and international theses with the rates of $15 \%$ and $25 \%$ respectively. In mixed research designs, according to Morse (2003), qualitative and quantitative paradigms can be given equal status or dominant status or can be integrated into concurrent or sequential mixed methods research (Baki \& Gökçek, 2012: 10-11). Therefore, in addition to combination of qualitative and quantitative paradigms, it was found that qualitative and qualitative or quantitative and quantitative research designs were preferred. In this regard, three classifications were identified: qualitative+qualitative, quantitative+quantitative and qualitative+quantitative. The least favorable research paradigm both in national and international theses was quantitative+quantitative. The number of qualitative+qualitative research designs, on the 
other hand, was marginally higher than qualitative+quantitative designs with a $0.91 \%$ difference for national theses and $0.49 \%$ for international theses. This indicates that use of these two designs showed similar rates.

It seems that differences among the national and international theses in terms of research design and methods played a role in the distribution of data collection tools. The number of data collection tools differed from the number of theses particularly due to the implementation of mixed research methods/design.

Figure 4. Data Collection Tools in National and International Theses
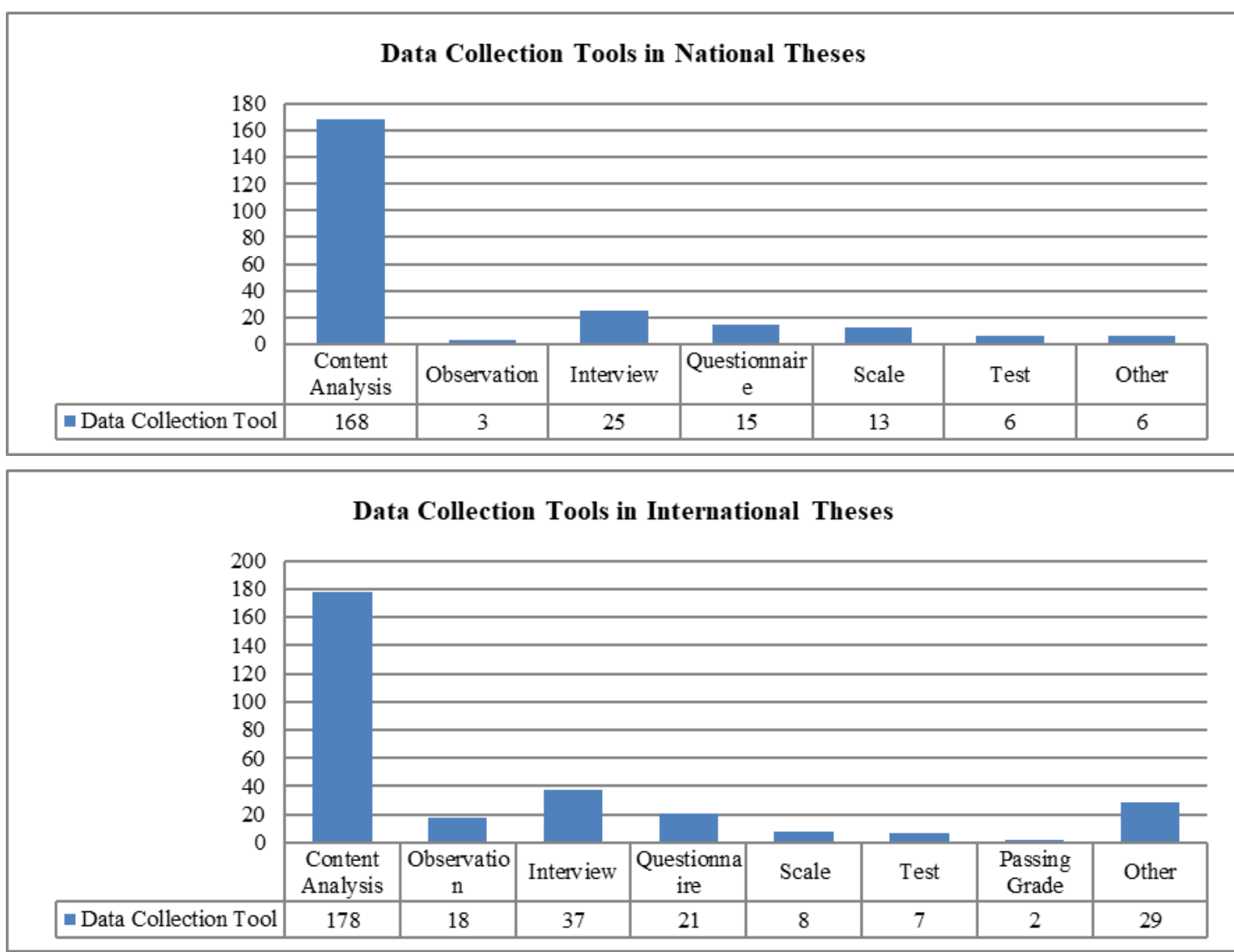

As can be seen in Figure 4, content analysis was the most preferred data collection tool for both of the theses types. The frequency rates of national and international theses seem to be similar (National-f:168; International-f:178). This is followed by observation and questionnaire respectively. While the frequencies of observation and questionnaire were 25 and 15 respectively in national theses, observation and questionnaires were utilized for 37 and 21 times respectively in international theses. While this frequency order was followed by scale, test and observation in national theses, the order in international theses was followed by observation, scale, test and passing grade respectively. National and international theses do not seem to differ greatly in terms of utilizing scales and tests (National- $\sum \mathrm{f}$ : 19; International- $\left.\sum \mathrm{f}: 15\right)$. However, there are differences in terms of observation. Observation was used more in international theses compared to national theses. It is also notable that passing grade was used in international theses as a data collection tool. In addition, several multi-dimensional data collection tools were also used such as voice and video recordings of oral reading speed, responses given to understand a 
text, pictures drawn by children about a novel, diaries and reflective journals, digital recordings, web analysis, field notes, researcher notes, video recordings, discussion recordings, reports, logbooks/training records, photographs, vignettes, sessions for choosing books and electronic records of correspondence. In national theses, on the other hand, tools that are included under the title of "others" are forms for evaluating and recording documents. This shows that international theses differ from national theses in terms of variation in data collection tools.

\section{Distribution of theses according to study groups/samples}

Study groups/ samples in national and international theses consist of "students, teacher candidates, teachers, printed materials and others" categories. "Students" category covers a wide range of students from each level including pre-school and higher education. However, teacher candidates were classified as a separate category from students of higher education institutions. Teacher candidates were from several departments such as Early Childhood Education, Turkish Language Teaching and English Language Teaching and Mathematics Teaching. Printed materials include printed books as well as studies on magazines and newspapers. The distribution of national and international theses by study groups is given in Figure 5.

Figure 5. Study Groups in National and International Theses

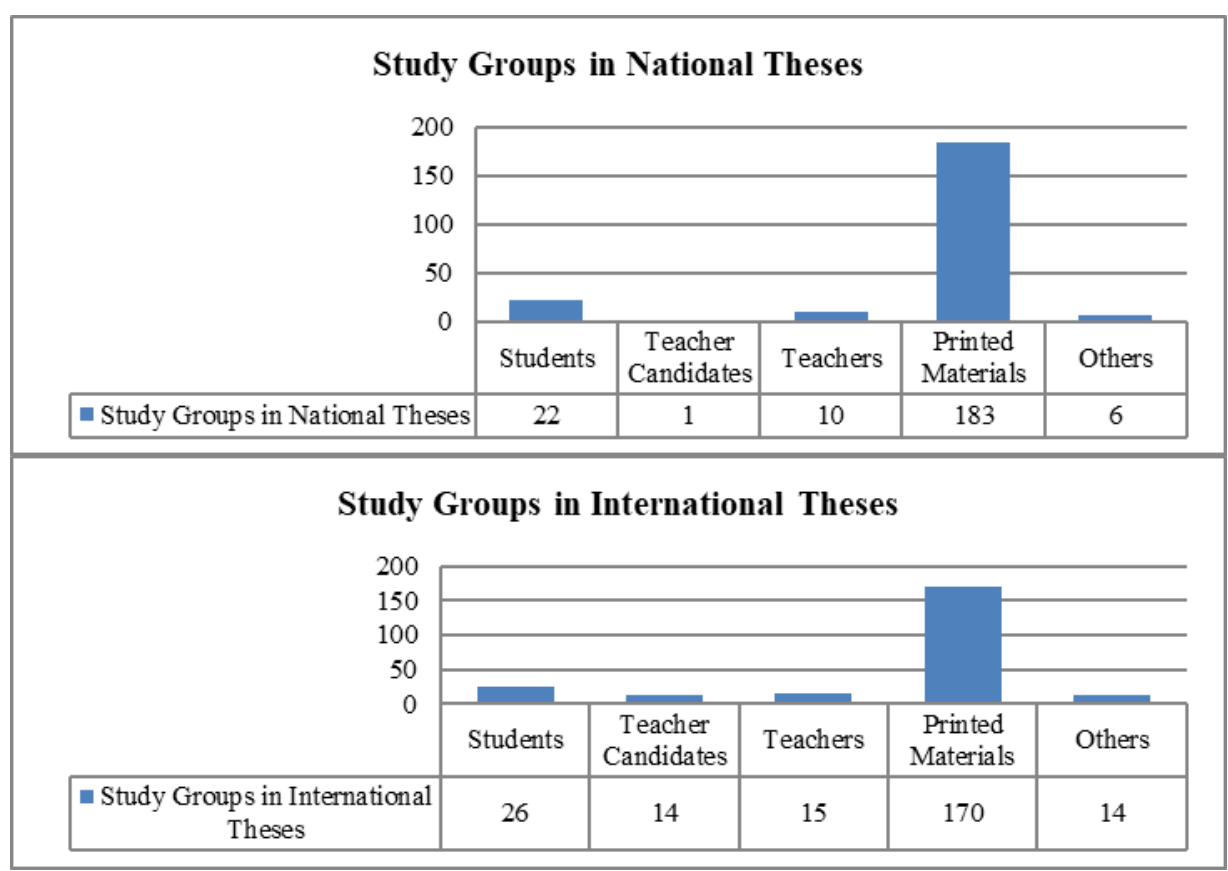

As is seen in Figure 5, the most preferred study groups were printed materials in both national and international theses. Printed materials were investigated in 183 of national theses and 170 of international theses. This study group is followed by students. Study groups of 22 national and 26 international theses consist of students. Both theses types were conducted with students from different levels of education. For instance, preschoolers in 3 theses, primary school students in 14 theses, middle-school students in 5 theses, high school students in 2 theses and higher education students (other than teacher candidates) in 2 theses were chosen as study groups in international theses. While the number of international theses with teacher candidates as a study group was 15 , the 
number of national theses in the same category were 10. Although the studies conducted with teachers are similar in frequency, national and international theses differ greatly in terms of utilizing teacher candidates as a study group. A total of 14 international theses were conducted with teacher candidates while only 1 national thesis was conducted with the same group. The frequency rate in international theses is similar to studies conducted with teachers (Teachers $\sum$ f: 15; Teacher Candidates- $\sum$ f:14). In national theses, audio materials were also used as a study group (f:6). In international theses, on the other hand, use of various study groups is notable: native Japanese and English speakers, psychologists, rabbi, social services specialists, writers, illustrators, critics and publishing house owners, parents, school principals and consultants, specialists in blogs, exhibitions, media, and readings.

\section{Distribution of theses according to research topics}

Common and different research topics in national and international theses are given in Table 3.

Table 3. Research Topics in National and International Theses

\begin{tabular}{|c|c|c|c|}
\hline \multicolumn{2}{|c|}{ Common Topics } & \multicolumn{2}{|l|}{ Different topics } \\
\hline \multirow{21}{*}{ 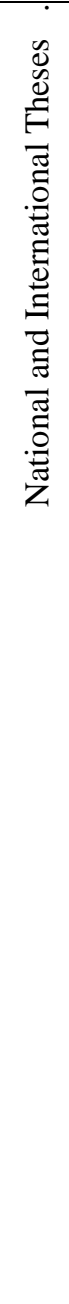 } & Children's literature's relation to various disciplines & Children's literature and children's library & \multirow{15}{*}{ 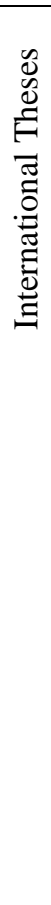 } \\
\hline & Fiction in children's literature & Children's literature and cultural & \\
\hline & Function of children's literature in education & Children's literature and social reality, sociology & \\
\hline & Children's literature and writer & Children's literature and games & \\
\hline & Character as an element of children's literature & Children's literature and museums & \\
\hline & Ideology and children's literature & Location as an element of children's literature & \\
\hline & Historical context and children's literature & Children's literature and quality of books & \\
\hline & Visual elements and children's literature & Relationship between children's and adult's literature & \\
\hline & Distinctive characteristics of children's literature & Time as an element of children's literature & \\
\hline & Children's literature and periodicals & Children's literature and religious reflection & \\
\hline & Text types in children's literature & Children's literature and sexuality & \\
\hline & Children's literature and contrastive children's & Children's literature and the child's world & \\
\hline & literature & Children's literature and readers & \\
\hline & Children's literature and language use & Children's literature and humor & \\
\hline & \multirow[t]{7}{*}{ Children's literature and translation } & Children's literature and environmental awareness & \\
\hline & & Messages in children's literature & \multirow{6}{*}{ 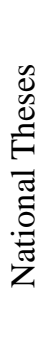 } \\
\hline & & Themes in children's literature & \\
\hline & & Elements that weaken children's literature & \\
\hline & & Children's literature in different countries & \\
\hline & & Theoretical approaches towards children's literature & \\
\hline & & Children's literature and drama & \\
\hline
\end{tabular}

As listed in Table 3, national and international theses share 14 common research topics while they differ in terms of 21 research topics. International theses, regarding the 
topics that differ, seem to have a greater scope (f:15) compared to national theses (f:6). In this vein, frequency of the research topics that international theses dealt with is $\sum \mathrm{f}: 29$ while this rate is $\sum \mathrm{f}: 20$ for national theses.

Figure 6.1. Distribution of Research Topics in National Theses
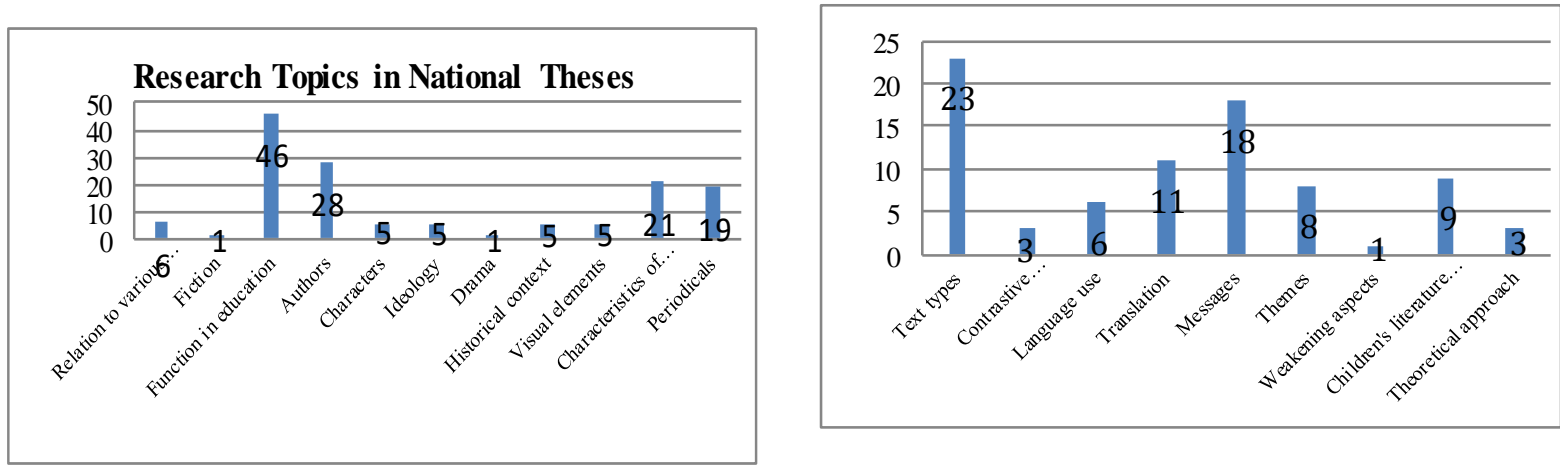

Figures 6.1 and 6.2 provide the frequencies of national and international theses' distribution of research topics. As is shown in Figure 6.1, the most common research topic in national theses is the function of children's literature in education (f:46). This is followed by research on children's literature writers (f:28) and text types in children's literature (f:23). The fourth most common research topic is distinctive characteristics of children's literature (f:21) followed by periodicals (f:19), messages (f:18), translation and children's literature (f:11), children's literature and different countries (f:9), themes (f:8), its relation to various disciplines and language use (f:6), characters, ideology, historical context and visual elements (f:5), theoretical approach and contrastive children's literature (f:3), fiction, drama and aspects that weaken children's literature (f:1) respectively.

Figure 6.2. Distribution of Research Topics in International Theses
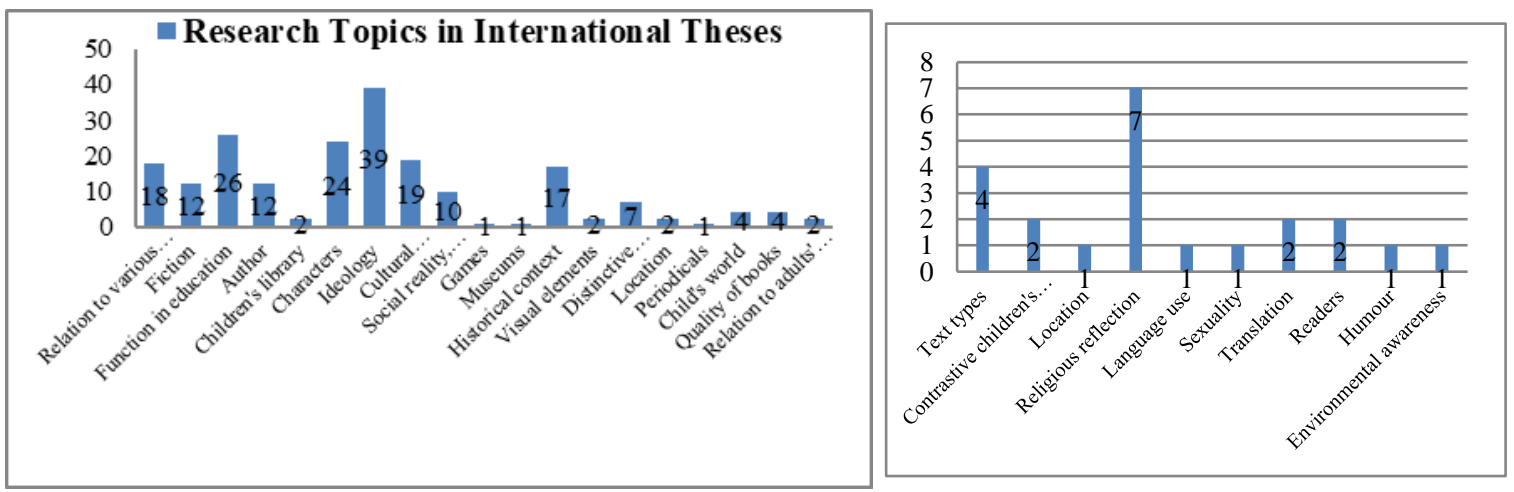

It can be seen in Figure 6.2 that the most common research topic in international theses is the reflections of ideologies on children's literature (f:39). The second most common topic is function of children's literature in education (f:26). Studies on characters, as one of the basic elements in children's literature, also stand out (f:24). These are followed by cultural transmission/reflection (f:19), relation to various disciplines (f:18), historical context (f:17), fiction and writers (f:12), social reality/sociology (f:10), distinctive characteristics of children's literature and religious reflection (f:7), the child's world, quality of books and text types (f:4), children's library, visual elements, location, relation to adults' literature, contrastive children's literature, translation and readers (f:2), 
games, museums, periodicals, time, language use, sexuality, humor and environmental awareness (f:1).

Differences in relation to sub-fields of research topics between national and international theses are also noteworthy. Among national theses whose research topic was relation of children's literature to other disciplines, the addressed disciplines are social sciences (f:3), social pedagogy (f:1), geography (f:1), health science (disability, f:1) while these disciplines are psychology (f:8), media (f:2), mathematics (f:1), music (f:1), journalism (f:1), social studies (f:1), philosophy (f:3) and narratology (f:1) in international theses.

It was found that national theses on the functions of children's literature in education attempted to associate the following aspects with children's literature: teaching reading (f:12), values education (f:20), affective education (empathy, leadership, achievement motivation, $\mathrm{f}: 4$ ), listening education (f:2), nutrition education (f:1), character education (f:2), concepts education (f:1), foreign language teaching (f:3) and native language teaching (f:1). In international theses, on the other hand, the following aspects were addressed from the view of children's education: teacher education (f: 4), morals education ( $\mathrm{f}: 2$ ), reading education ( $\mathrm{f}: 8)$, teaching mathematics (f:4), special education (f:1), child-care education (f:1), democracy education (f:1), social studies education (f:1), character education (f:2), program development (f:1) and science education (f:1).

In national theses on ideology, sub-fields of children's rights (f:1), politics (f:1) and sexism (f:3) were addressed: However, the scope of sub-fields in international theses on the same research topic seems to be broader with the following aspects: politics (f:2), feminism and woman image (f:5), gender roles and perceptions (f:3), discrimination and gender apartheid (f:6), racism (f:13), banned books (f:1), republicanism (f:1), fascism (f:1) and nationalism (f:3).

In relation to cultural transmission and reflection, which were commonly studied in international theses but not addressed in national theses, it was found that the researchers often dealt with multiculturalism and comparisons of local and hybrid cultures. Social reality, another research topic which was not addressed in national theses, was discussed in international theses in terms of homosexuality, mixed-race, local community, social class and myths.

A total of 23 national theses were conducted on text types. The sub-fields in them are comic books (f:2), poems (f:1), tales (f:9), fairy tales/lullabies (f:2), novels (f:5), religious advice books (f:2), epics (f:1) and biographies (f:1). Only a few text types were addressed in international theses: science fiction ( $f: 1)$, transmedia texts (f:1), poems (f:1) and didactic texts (f:1). It is interesting that religious reflection was not investigated in national theses while international theses addressed such issues as Judaism, Christianity and religious ideologies.

Distinctive characteristics of children's literature were handled in national theses in terms of basic principles of children's literature (f:13), suitability to the child and child's reality (f:8) while the same research topic was discussed in international theses in terms of child's reality (f:1), concept of child, child image (f:4) and creativity (f:1). Moreover, 
within the context of the child' world, effects of periods on child characters (f:1), menstrual cycle (f:1), child's needs (f:1) and puberty (f:1) were discussed.

Messages and themes in children's literature, aspects that weaken children's literature, different countries and children's literature and theoretical approach to children's literature are common only in national theses. In terms of different countries and children's literature, studies were conducted on literary works from Kosovo (f: 2), Macedonia (f: 1), Bulgaria (f: 1), Iran (f: 1), Spain (f: 1), Iraq (f: 1) and Kashgar Turks (f: 1) and Arabs (f: 1).

While national theses discussed visual elements in children's literature in terms of pictures (f:2), digital illustration (f:1) and design (f:2), there are only 2 international theses on this topic. Only 5 national theses were conducted on characters as basic elements of children's literature while the number of international theses on the same topic is 24 . Characters were investigated and evaluated from several aspects in international theses. Some of these aspects are as follows: man, woman and child, orphan, bad, disabled and savior/heroes, secondary (supporting) characters, princess, mad scientist, humanized animal characters, personality and ethnic traits of characters, search for identity and belief status.

\section{Discussion}

In this study aiming to analyze national and international theses conducted between 2010 and 2019 on children's literature, a total of 429 theses including 220 national and 209 international theses were investigated. Firstly, the distribution of theses regarding gender of the authors was identified. More than half of the national and international theses were found to have been conducted by female authors. It has been reported in the study by Yildiz (2018) that female academicians, both in Turkey and United States, are highly interested in social matters. This supports the finding that most of the studies on children's literature were conducted by female researchers.

When it comes to the distribution of theses by year, the findings show that the distribution of both national and international theses from 2010 to 2019 is not balanced. The number of national theses was highest in 2011 while 2013 and 2012 were the years with the highest number of international theses. In Yazıc1's study (2013), a total of 76 theses were accessed that were conducted between 2010 and 2012 (November 2012). This indicates that 14 more theses were added to the system between November 2012 and December 31, 2012. Additionally, Yazıc1 (2013) reports that the theses published between 2010 and 2012, just two years, are more than the theses published between 2000 and 2009. In this study as well, the number of theses published between 2010 and 2012 is 90 while 130 theses were published between 2013 and 2019 (until June), which shows that the period between 2010 and 2012 is a productive interval in terms of theses on children's literature. For international theses, the period between 2010 and 2013 seems to be productive while there is a notable decrease in the number between 2014 and 2017.

When compared in terms of graduate level, master's theses are more at national level while doctoral theses are prevalent at international level. According to Higher Education Information Management System, there are 394174 master's students and 
96199 doctoral students in Turkey (yok.gov.tr, 2019). The fact that master's students are four times higher than doctoral students is in line with the domination of master's theses. However, it was found that international theses are composed of mainly doctoral theses, which can be explained by the interest of several departments in children's literature studies. Departments of Literature Thought and Culture, Language and Literacy, English Language and Literature, and Departments of Educational Sciences including Preschool, Primary School, Language Skills and Curriculum appear to be interested in studies on children's literature, which can positively influence the number of theses. The fact that doctoral programs are offered two ways as either $\mathrm{EdD}$ or $\mathrm{PhD}$ in several countries can also have an effect. Still, several other variables should be considered as to the differences between graduate levels; researchers at doctoral level may be more interested in children's literature studies or scope of the studies conducted may be assumed to be appropriate to only doctoral level.

In terms of the research design that national and international theses adopted, qualitative approaches were found to be more preferred with an extensive use of content analysis. In the studies conducted by Şahin, Kana and Varışoğlu (2013), Ertekin and Çamlıbel Çakmak (2019) and Balta (2019), qualitative approaches were reported to be more favorable. In Boyacı and Demirkol's study (2018) as well, qualitative studies were found to be more common with the rate of $39 \%$. In this respect, the findings related to the national theses in this study are similar to the reported findings in literature. According to Hsu (2005) and Demir and Koçyiğit (2018), international studies tend toward quantitative and qualitative, and the most commonly used design is qualitative, which supports this study's findings as to the prevalence of qualitative design in international theses.

The results indicate that mixed methods design was adopted more in international theses with a rate of $25 \%$ than in national theses, which utilized the design with a rate of 15\%. Sözbilir, Kutu and Yaşar (2012), in their study on the trends in science education research in Turkey, conclude that $66.8 \%$ of 1249 studies were quantitative, $30 \%$ were qualitative and $3.2 \%$ were mixed design. However, they considered only qualitative and quantitative design as a type of mixed design research. The rate of mixed methods design in this study is $6.36 \%$. Therefore, utilizing mixed methods research seems not to be a popular trend in Turkey for the time being. It was concluded in the same study, related to the trends in data collection tools in Turkey, that the number of studies which used more than two data collection tools is few. This conclusion is not different in terms of the findings pertaining to national theses on children's literature given the fact that only seven theses collected data through three instruments. For international theses, a mixed methods research trend is relatively obvious with one fourth of the reviewed theses that adopted a mixed methods design. Besides, there are studies (f:2) that utilized six data collection tools while the trend is often three data collection tools. Truscott et al. (2010) examined the prevalence of mixed method research in the studies published in 11 leading English-language international and U.S. national educational journals between 1995-2005, and concluded that, out of 2381 studies (on literacy, mathematics, social studies, and science), 332 (14\%) utilized mixed methods. It was observed in this study that qualitative and quantitative design was used in $11 \%$ of international theses, which is in line with the 
reported literature. Ross and Onwuegbuzie (2010) also report that mixed methods research accounted for $33 \%$ of the articles published in journals, and that almost half of these studies were qualitative in orientation. Qualitative oriented mixed methods approach in international theses $(11.49 \%)$ constitute approximately the half, which suggests that this type of mixed methods research is preferred in international literature.

The most popularly used data collection tool, both in national and international theses, is content analysis followed by interviews and questionnaires. The use of questionnaires as the single data collection tool in national theses is more than international theses in number. A number of studies have reported frequent uses of document analysis, interviews and questionnaires (Varışoğlu, Şahin \& Göktaş, 2013; Çam Aktaş, 2016; Biçer, 2017; Dündar \& Hareket, 2017; Erdem, 2018; Türkben, 2018; Balta, 2019; Veyis, 2020). Therefore, prevalence of document analysis or questionnaires as data collection tools reveals the need for more multi-dimensional tools in national theses. Although document analysis is also prevalent in international theses, the number of theses that utilized various data collection tools is not few (f:39). For this reason, there is a need for variation in data collection tools for national theses.

Considering the population/sampling or study groups in national and international theses, the most popular type is printed materials, and the studies conducted with teachers are at similar rates for both these types. However, studies conducted with teacher candidates is more prevalent among international theses. It is reported in the study by Göktaş et al. (2012) that the most preferred study group is teacher candidates and teachers. On the other hand, international theses included various study groups (psychologists, rabbis, social services specialists, writers, illustrators, critics and publishing house owners, parents, school principals and consultants, and specialists in blogs, exhibition, media, and reading).

In terms of the distribution of research topics, the most common topic in national theses is the function of children's literature in education while international theses dealt with ideological reflections on children's literature the most. Balta (2019) states that theses with a main focus on children's literature often deal with informative and educational messages. Balc1 (2012) reports that the most popular research topic in children's literature is literary texts with an emphasis on the increasing trends in children's literature and Turkish education over the years. The findings obtained in this study also show that children's literature studies related to education in general and Turkish education in particular still continue to be conducted. Furthermore, Yazic1 (2013) claims that one of the significant focus points of children's literature theses is on how a theme, message and or educational function is reflected in a particular literary work or several works from the same author.

Messages in children's literature, themes in children's literature, aspects that weaken children's literature, children's literature in different countries, theoretical approach to children's literature, children's literature and drama are research topics addressed in national theses. Children's library, cultural transmission/reflection, social reality-sociology, games, children's museums, locations in children's literature, quality of books, relationship between children's literature and adults' literature, time, religious 
reflection, sexuality, child's world, readers, humor, environmental awareness are research topics in international theses. The varied scope of international theses is notable. While national theses dealt with children's rights, politics and sexism in terms of ideology, international theses seem to have a wider scope in this matter: politics, feminism and woman image, gender roles and perceptions, discrimination and gender apartheid, racism, banned books, republicanism, fascism and nationalism. Also, a number of topics that were not discussed in national theses were addressed in international theses such as multiculturalism, comparisons of local and hybrid cultures, homosexuality, social class and myths.

Social reality plays a significant role in the examination of these topics in international theses. The Council on Interracial Books for Children (CIBC), which was established in 1965 on the heels of Human Rights Movement in 1960, have played a critical role in the promotion of children's literature which can reflect the multi-racial society. In addition to addressing issues of racism and sexism in children's literature, $\mathrm{CIBC}$ has an interest in the place of African Americans, Asians, Latinos, Native Americans and woman in children's literature (Banfield, 1998). Thus, these issues were prevalently addressed as a result of a multi-racial and multi-cultural society. This is also reflected in addressing characters. International theses discussed characters from various points of views: man, woman and child, orphan, bad, disabled and savior/heroes, secondary (supporting) characters, princess, mad scientist, humanized animal characters, personality and ethnic traits of characters, search for identity and belief status. Such an analysis on characters seems to be superficial in national theses. So, national theses need to question on "what realities" the literary products written for children are structured,and based on what realities a childhood policy is developed. National theses should be structured and developed on the basis of international theses in terms of both research topics and research procedures.

\section{Conclusion}

Research topics in national theses seem to follow the same cycle approaching children's literature from a theoretical point of view. Topics on principles, components and developments in children's literature were addressed. However, it is also essential to perceive children as adults, to know about children's world and their needs and to study on the impacts of children's developmental periods on personality traits. National theses also seem to have failed to study on children's natural curiosity and creativity. Distinctive characteristics of children's literature should not be narrowed down to basic principles of children's literature, suitability to the child and child's reality but more issues such as child concept, child image and creativity should be addressed. Considering children's identification with characters, more studies should provide an in-depth analysis on characters. It is therefore crucial to expand the research topics in further theses on children's literature.

It is also recommended for further theses on children's literature to make use of mixed methods research rather than quantitative designs, to indicate research methods and design clearly together with data collection tools and to include basic facts about the theses 
in the abstract section. These requirements can only be fulfilled by following guidelines for thesis writing accurately and making sure that they are fulfilled. Guidelines are important for thesis writing so as to ensure appropriate organization that is in line with the issues and that these issues are clearly stated in the scientific research. Regarding the differences between theses in terms of format and content, these guidelines should be clear, accepted by all universities and functional.

\section{References}

Akaydın, Ş. \& Çeçen, M. A. (2015). A content analysis on articles related to reading skills. Education and Science, 40(178), 183-198. http://dx.doi.org/10.15390/EB.2015.4139

Aktaş, E. \& Uzuner Yurt, S. (2015). A content analysis for article abstracts in Turkish education area. Turkish Studies, 10(7), 73-96. http://dx.doi.org/10.7827/TurkishStudies.8121

Alpkiray, F. \& Samur, Y. (2017). A content analysis of thesis and dissertations published in Turkey on electronic books. SDU International Journal of Educational Studies, 4(1), 1228.

Altunya, H. (2012). Türk çocuk edebiyatı kaynakçası [Turkish children's literature bibliography]. Ankara: Ankara Üniversitesi Basımevi.

Alver, M. \& Taştemir, L. (2017). Examination of Postgraduate Thesis on Speaking Skills. International Journal of Languages' Education and Teaching, 5(3), 451-462. http://dx.doi.org/10.18298/ijlet.2041

Baki, A. \& Gökçek, T. (2012). A general overview of mixed method researches. Elektronik Sosyal Bilimler Dergisi, 11(42), 1-21. Retrieved from https://dergipark.org.tr/en/pub/esosder/issue/6156/82721

Balcı, A. (2012). Türkiye'de çocuk edebiyatı üzerine hazırlanan lisansüstü tezler hakkında bir meta-analiz çalışması [A meta-analysis study on post-graduate theses written on children's literature in Turkey]. Mustafa Kemal University Journal of Graduate School of Social Sciences, 9(17), 195-206. $\quad$ Retrieved from https://dergipark.org.tr/tr/pub/mkusbed/issue/19553/208286

Balta, E. E. (2019). Çocuk edebiyatı üzerine yapılmış lisansüstü çalışmaların içerik analizi (20112018 y1lları) [A content analysis post-graduate studies in Turkey about children's literature (2011-2018 period)]. OPUS Uluslararası Toplum Araştırmaları Dergisi, 10(17), 464-489. Retrieved from https://dergipark.org.tr/tr/pub/opus/issue/42322/510809

Banfield, B. (1998). Commitment to change: the council on interracial books for children and the world of children's books. African American Review, 32 (1), 17-22. Retrieved from https://eric.ed.gov/?id=EJ566984

Biçer, N. (2017). Yabancılara Türkçe öğretimi alanında yayınlanan makaleler üzerine bir analiz çalışması [An Analysis Study on the Published Articles Relating to the Field of Teaching Turkish to Foreigners]. Pamukkale Üniversitesi Sosyal Bilimler Enstitüsü Dergisi, 27, 236247. http://dx.doi.org/10.5505/pausbed.2017.69772

Boyacı, S. \& Demirkol, S. (2018). Türkçe eğitimi alanında yapılan doktora tezlerinin incelenmesi [An examination of doctoral dissertations in the field of teaching Turkish]. Ana Dili Eğitimi Dergisi, 6(2), 512-531. https://doi.org/10.16916/aded.363599

Bozkurt, B. Ü. \& Uzun, N. E. (2015). Türkçenin eğitimi-öğretimine ilişkin bir alanyazını değerlendirmesi: uluslararası bilimsel toplantılarda eğilimler/yönelimler [A review of literature on Turkish language education: trends in international conferences]. Journal of Language Education and Research, 1(2), 1-15. Retrieved from https://dergipark.org.tr/tr/pub/jlere/issue/18968/200358?publisher=jlere 
Büyükikiz, K. (2014). Yabancılara Türkçe öğretimi alanında hazırlanan lisansüstü tezler üzerine bir inceleme [An investigation on graduate dissertations written on Turkish teaching as a foreign language]. Mustafa Kemal University Journal of Graduate School of Social Sciences, 11(25), 203-213. Retrieved from https://dergipark.org.tr/en/download/articlefile/183334

Büyüköztürk, Ş., Çakmak, E. K., Akgün, Ö. E., Karadeniz, Ş. \& Demirel, F. (2009). Bilimsel araştırma yöntemleri [Scientific research methods]. (5th ed.). Ankara: Pegem A Yayınc1lik.

Ceran,D., Aydın, M. \& Onarıcıoğlu, A. S. (2018). Okuma eğitimi üzerine yapılan tezlerde eğilimler: bir içerik analizi çalışması [Trends in theses on reading education: a content analysis study]. Ahi Evran Üniversitesi Kırşehir Eğitim Fakültesi Dergisi (KEFAD), 19(3), 2377-2392. http://dx.doi.org/10.29299/kefad.2018.19.03.016

Coşkun, E., Özçakmak, H. \& Balc1, A. (2012). Türkçe eğitiminde eğilimler: 1981- 2010 yılları arasında yapılan tezler üzerine bir meta-analiz çalışması [Trends in Turkish education: A meta-analysis study on theses conducted between 1981-2010]. In E. Y1lmaz, M. Gedizli, E. Özcan and Y. Koçmar, (Ed.), Türkçenin Ĕ̈itimi Öğretimi Üzerine Çalışmalar (pp. 204212). Ankara: Pegem Akademi Yayıncılık.

Çam Aktaş, B. (2015-2016). Türkiye'de eleştirel okuma kapsamında gerçekleştirilen çalışmaların incelenmesi [An evaluation of researches done on critical reading in Turkey]. Akademik Araştırmalar Dergisi, 17(67- Türkçe Öğretimi Özel Sayıs1), 217-232. Retrieved from https://earsiv.anadolu.edu.tr/xmlui/bitstream/handle/11421/14861/14861.pdf?sequence=1

Değirmenci Gündoğmuş, H. (2018). Okuduğunu anlama ile ilgili yapılan lisansüstü tezlerin incelenmesi [The analysis of the graduate thesis related to reading comprehension]. Turkish Studies, 13(3), 899-910. http://dx.doi.org/10.7827/TurkishStudies.13218

Demir, Y. \& Koçyiğit, M. (2018). A Systematic Review of Research on English Language Teacher Education Published in Three Flagship Journals (1997-2016). EKUAD [JETPR], 4(1), 128138. Retrieved from http://ekuad.com/articles/a-systematic-review-of-research-on-englishlanguage-teacher-education-published-in-three-flagship-journals-1997-2016.pdf

Demircan, C. (2007). Çocuk edebiyatı konulu lisansüstü çalışmalar ile ilgili bir durum araştırması [A case study on graduate studies about children's literature]. Sakarya Üniversitesi Eğitim Fakültesi Dergisi, 13, 23-35. Retrieved from https://dergipark.org.tr/tr/pub/sakaefd/issue/11226/134022

Dilidüzgün, S. (2003). Illetişim odaklı Türkçe derslerinde çocuk kitapları [Children's books in communication-oriented Turkish lessons]. İstanbul: Morpa Yayını.

Dilidüzgün, S. (2004). Çağdaş çocuk yazını kitapları [Contemporary children's literature books]. İstanbul: Morpa Yayınları.

Dilşad Ertekin, B. \& Çamlıbel Çakmak, Ö. (2019). Okulöncesi eğitim literatüründeki resimli çocuk kitaplarına yönelik yapılan lisansüstü tezlerin incelenmesi [An overview of postgraduate theses within the field of illustation children books at early childhood education]. Journal of Social and Humanities Sciences Research, 6(40), 2111-2124. Retrieved from http://www.jshsr.org/Makaleler/1659868954_18_2019_640.ID1324.\%20ERTEK\%c4\%b0N\&\%c3\%87AKMAK-\%202111-2124.pdf

Doğan, Y. \& Özçakmak, H. (2014). Dinleme becerisinin eğitimi üzerine yapılan lisansüstü tezlerin değerlendirilmesi [Evaluation of the graduate theses performed on listening skills' education]. Journal of Mother Tongue Education, 2(2), 90-99. https://doi.org/10.16916/aded.46766

Erdem, C. (2018). Medya okuryazarlığı araştırmalarında eğilimler: lisansüstü tezlere yönelik bir içerik analizi [Trends in media literacy research: a content analysis of postgraduate 
dissertations]. Journal of Theoretical Educational Science, 11(4), 693-717. http://dx.doi.org/10.30831/akukeg.390260

Eski, B. (2019). Türkiye'de dramayla dil eğitimi alanında yapılan lisansüstü araştırmaların eğilimleri [Tendencies of postgraduate researches in the field of language education by creative drama]. Social Sciences: Theory \& Practice, 3(2), 53-64. Retrieved from https://dergipark.org.tr/tr/download/article-file/910468

Fidan, M. (2019). Çocuk edebiyatı eserlerini değerler eğitimi yönünden inceleyen lisansüstü tezlerin analizi [Analysis of postgraduate theses examining children's literature works in terms of values education]. In M. B. Minaz \& M. Sert A ğır (Ed.), Eğitim Bilimleri Alaninda Araştırma Makaleleri (pp.231-246). Ankara: Gece Akademi.

Göktaş, Y., Hasançebi, F., Varışoğlu, B., Akçay, A., Bayrak, N., Baran, M. \& Sözbilir, M. (2012). Trends in educational research in Turkey: a content analysis. Educational Sciences: Theory \& Practice, 12(1), 455-460. Retrieved from https://files.eric.ed.gov/fulltext/EJ978453.pdf

Hsu, T. (2005) Research methods and data analysis procedures used by educational researchers, International Journal of Research and Method in Education, 28(2), 109-133. http://dx.doi.org/10.1080/01406720500256194

Hunt, P. (2005). Introduction: the expanding world of children's literature studies. In P.Hunt (Ed.), Understanding Children's Literature (pp.1-14). London: Routledge.

Kantarcioğlu, S. (1991). Eğitimde masalın yeri [The importance of fairy tales in education]. Ankara: Millî Eğitim Bakanlığı Yayınları- Öğretmen Kitabı Dizisi.

Karakaya, İ. (2014). Bilimsel araştırma yöntemleri [Scientific research methods]. In A.Tanrı̈ğen, (Ed.), Bilimsel Araştırma Yöntemleri [Scientific research methods] (pp.55-84). Ankara: Anı Yayınc1l1k.

Kurt, A. \& Erdoğan, M. (2015). Program değerlendirme araştırmalarının içerik analizi ve eğilimleri; 2004-2013 yılları arası [Content Analysis and Trends of Curriculum Evaluation Research: 2004- 2013]. Education and Science, 40(178), 199-224. http://dx.doi.org/10.15390/EB.2015.4167

Küçük, S. \& Kaya, E. (2018). Yabancı dil olarak Türkçe öğretimi ile ilgili hazırlanan tezlerde geçen anahtar kelimelere yönelik içerik analizi [Content analysis of the keywords in the dissertations on teaching Turkish as a foreign language]. Journal of History Culture and Art Research, 7(5), 442456. http://dx.doi.org/10.7596/taksad.v7i5.1880

Lynch-Brown, C. \& Tomlinson, C. M. (1999). Essentials of children's literature. (3th Ed.). Needham, Massachusetts: Allyn and Bacon.

Neydim, N. (2003). Çocuk edebiyatı [Children's literature]. İstanbul: Bu Yayınevi.

Özdemir, S. (2018). Okumaya ilişkin lisansüstü araştırmaların eğilimleri [Research Trends in Postgraduate Studies on Reading]. Journal of Mother Tongue Education, 6(4), 1161-1178. https://doi.org/10.16916/aded.455560

Potur, Ö. \& Yıldız, N. (2016). Konuşma becerisi alanında yapılan akademik çalışmaların eğilimleri [Tendencies of academic studies in speaking skills field]. Journal of Language and Literature Education, 18, 27-40.

Sever, S. (2003). Çocuk ve edebiyat [Child and literature]. Ankara: Kök Yayıncılık.

Sevim, O. \& İşcan, A. (2012). Türkçenin eğitimi ve öğretimi alanında yapılan yüksek lisans tezlerinde geçen anahtar kelimelere dönük bir içerik analizi [A content analysis of keyword of theses in the field of Turkish education and teaching]. Turkish Studies, 7(1), 1863- 1873. http://dx.doi.org/10.7827/TurkishStudies.3101

Sevim, O. \& Özdemir Erem, N. H. (2012). Türkçe eğitimi alanındaki yüksek lisans tezlerinin başlıklarına ve özetlerine eleştirel bir bakış [A critical evaluation to abstracts and titles of 
master thesis in Turkish language education]. TEKE [International Journal of Turkish Literature Culture Education], 1 (3), 174-186.

Sözbilir, M., Kutu, H. \& Yaşar, M. D. (2012). Science education research in Turkey: A content analysis of selected features of papers published. In J. Dillon\& D. Jorde (Eds), The World of Science Education: Handbook of Research in Europe (pp.341-374). Rotterdam: Sense Publishers.

Şahin, E. Y., Kana, F. \& Varışoğlu, B. (2013). Türkçe eğitimi bölümlerinde yapılan lisansüstü tezlerin araştırma eğilimleri [The research trends of postgraduate dissertations in Turkish education departments]. International Journal Of Human Sciences, 10(2), 356- 378.

Şeref, İ. (2019). Türkçe öğretiminde şiir üzerine yapılan lisansüstü tezlerin değerlendirilmesi [An evaluation of postgraduate theses on poetry in Turkish teaching]. I $\breve{g} d \imath$ Üniversitesi Sosyal Bilimler Dergisi, 20, 335-349.

Şirin, M. R. (Ed.). (2000). 99 soruda çocuk edebiyatı [Children's literature in 99 questions] (3th ed.). İstanbul: Çocuk Vakfı Yayınları.

Tanrıverdi, B. \& Apak, Ö. (2013). Görsel okuryazarlık üzerine bir içerik analizi [A content analysis on visual literacy]. Uludă̆ Üniversitesi Ĕgitim Fakültesi Dergisi, 26 (1), 267-293. Retrieved from https://dergipark.org.tr/tr/download/article-file/153503

Tok, M. \& Potur, Ö. (2015). Yazma eğitimi alanında yapılan akademik çalışmaların eğilimleri (2010-2014 y1llar1) [Trends of the academic studies in writing education area (2010 - 2014 years)]. Ana Dili Eğitimi Dergisi, 3(4), 1-25. Retrieved from http://www.anadiliegitimi.com/en/download/article-file/14934

Truscott, D.M., Swars, S., Smith, S., Thornton-Reid, F., Zhao, Y., Dooley, C., Williams, B., Hart, L. \& Matthews, M. (2010). A cross-disciplinary examination of the prevalence of mixed methods in educational research: 1995-2005. International Journal of Social Research Methodology, 13 (4), pp.317-328 https://doi.org/10.1080/13645570903097950

Turan, L., Sevim, O. \& Tunagür, M. (2018). Türkçe eğitimi alanındaki doktora tezlerinin özet bölümlerine yönelik bir içerik analizi [A content analysis for the summary sections of doctoral theses in the field of Turkish education]. Uluslararası Türk Eğitim Bilimleri Dergisi, 11, 29-44. Retrieved from https://dergipark.org.tr/tr/download/article-file/554688

Türkben, T. (2018). Yabancı dil olarak Türkçe öğretimi alanında yapılan lisansüstü çalışmaların değerlendirilmesi [Evaluation of postgraduate studies conducted on teaching Turkish as a foreign language]. TEKE [International Journal of Turkish Literature Culture Education], 7(4), 2464-2479. Retrieved from https://dergipark.org.tr/tr/download/article-file/623535

Varışoğlu, B., Şahin, A. \& Göktaş, Y. (2013). Türkçe eğitimi araştırmalarında eğilimler [Trends in Turkish education studies]. Kuram ve Uygulamada Eğitim Bilimleri [Educational Sciences:Theory and Practice], 13 (3), 1767- 1781.

Veyis, F. (2020). Türk dili ve edebiyatı eğitimi alanında lisansüstü araştırmalar üzerine bir inceleme [An investigation on graduate research in Turkish language and literature education]. Atatürk Üniversitesi Türkiyat Araştırmaları Enstitüsü Dergisi, 67, 683-702. https://doi.org/10.14222/Turkiyat4284

Yazıcı, N. (2013). Çocuk edebiyatı alanında üniversitelerde yapılan lisans sonrası çalışmalar [An analysis on the graduate studies on children's literature in universities]. Hacettepe Üniversitesi Eğitim Fakültesi Dergisi [H. U. Journal of Education], 28 (1), 441-452, Ankara. Retrieved from https://dergipark.org.tr/en/download/article-file/87153

Yıldırım, A. \& Şimşek, H. (2006). Sosyal bilimlerde nitel araştırma yöntemleri [Qualitative research methods in the social sciences]. (5th ed.). Ankara: Seçkin Yayınc1l1k.

Yıldız, M., Çoban Süral, Ü. \& Boz, İ. (2019). Türkiye'de okuduğunu anlamayı geliştirmeye dönük ilkokul düzeyindeki çalışmaların sistematik incelenmesi [Systematic review of the studies 
on improving reading comprehension in the primary school level in Turkey]. GEFAD / GUJGEF, 39(2), 1049-1086. https://doi.org/10.17152/gefad.548457

Yıldız, S. (2018). Türkiye'de kadın akademisyen olmak [Being a female academician in Turkey]. Journal of Higher Education and Science, 8(1), 29-40. https://doi.org/10.5961/jhes.2018.245 


\section{Dil Eğitimi ve Araştırmaları Dergisi}

Araştırma Makalesi

\section{Çocuk Edebiyatı Alanında Yapılan Ulusal ve Uluslararası Lisansüstü Tezler Üzerine Bir İçerik Çözümlemesi}

\begin{tabular}{|c|c|}
\hline MAKALE BİLGİSİ & ÖZ \\
\hline $\begin{array}{l}\text { Geliş 11.01.2021 } \\
\text { Düzeltme 04.04.2021 } \\
\text { Kabul11.04.2021 } \\
\text { Doi: } 10.31464 / \text { jlere.831792 } \\
\\
\text { Anahtar Sözcükler: } \\
\text { Çocuk edebiyatı } \\
\text { Ulusal tezler } \\
\text { Uluslararası tezler } \\
\text { İçerik çözümlemesi }\end{array}$ & $\begin{array}{l}\text { Bu çalışmada "çocuk edebiyatı" üzerine yapılan ulusal ve uluslararası } \\
\text { lisansüstü tezleri düzeyine (yüksek lisans/ doktora), yapıldığı yıllara, } \\
\text { konularına, araştırma sorularına, amacına, yöntemlerine ve veri } \\
\text { toplama araçlarına göre inceleyip değerlendirmek amaçlanmıştır. } \\
\text { Ulusal tezler için YÖK'ün Ulusal Tez Merkezi veri tabanından, } \\
\text { uluslararası tezler için ise ProQuest veri tabanından yararlanılmıştır. } \\
\text { Tez taraması, 2010-2019 yıllarında yapılan tezlerle sınırlandırılmıştır. } \\
\text { Doküman analizinden yararlanılan bu çalışmada çocuk edebiyatı ile } \\
\text { ilgili kavramlardan yola çıkılarak tezlere ulaşılmıştır. Veriler, } \\
\text { araştırmacılar tarafından geliştirilen form aracılığıly içerik } \\
\text { çözumlemesi ile elde edilmiştir. Araştırma sonucunda tezlerde kadın } \\
\text { araştırmacıların öne çıktığı; lisansüstü düzey ve y1l açısından ulusal ve } \\
\text { uluslararası tezlerin farklılaşma gösterdiği; nitel araştırmaların hem } \\
\text { ulusal hem uluslararası tezlerde en çok yeğlendiği; konu bağlamında } \\
\text { ulusal tezlerde çocuk edebiyatının eğitimdeki işlevi, uluslararas1 } \\
\text { tezlerde ise çocuk edebiyatında ideolojinin baskın bir biçimde ele } \\
\text { alındığı belirlenmiştir. }\end{array}$ \\
\hline
\end{tabular}

\section{Bilgilendirme}

Yayın Etik Açıklaması

Yazarlar, bu makalenin tüm sorumluluğunu üstlenmektedir. Ayrıca derginin tüm kurallarını da kabul etmektedir.

Yazarlar, kaynaklarda belirtilenler dışında hiçbir kaynağı kullanmadığını ve makalenin bir başka dergiye değerlendirilmek üzere gönderilmediğini onaylamaktadır.

Yazarların Katkı Oranı

Bu makaleye yazarlar eşit oranda katkı sağlamıştır.

Çıkar taşıması

Yazarlar çıkar çatışması olmadığını onaylamaktadır.

\footnotetext{
* Dr. Öğr. Üyesi, ORCID ID: https://orcid.org/0000-0003-1041-7558, Gaziantep Üniversitesi, Türkçe ve Sosyal Bilimler Eğitimi Bölümü, sevilhasirci@gmail.com

** Dr. Öğr. Üyesi, ORCID ID: https://orcid.org/0000-0002-7827-7638, Abant İzzet Baysal Üniversitesi, Türkçe ve Sosyal Bilimler $\quad$ Eğitimi Bölümü, $\quad$ aavsar06@gmail.com *** Bu çalışma, 10. Uluslararası Türkçenin Eğitimi-Öğretimi Kurultayı'nda (28-30 Eylül 2017) sunulan bildirinin genişletilmiş biçimidir.
} 


\section{Giriş}

Çocuk dünyasının doğallığını, çocuk duyarlılığını ve gerçekliğini iyi kavrayarak edebiyat ürünlerine yansıtmak önemlidir. Bu yüzden çocuk edebiyatının ayrı bir önem ve öncelikle değerlendirilmesi gerekmektedir. Çünkü "yazınsal değeri olan, çocuk gerçeklerini duyarlı olarak ele alan, çocuklara okuma sevgisi ve alışkanlığı verebilecek ve onlara nitelikli okur kimliği kazandırabilecek sanatsal değeri olan bu edebiyat, 4-12 yaş arası çocuklara yönelik yazınsal ürünleri kapsamaktadır" (Dilidüzgün, 2004: 18). Çocukları nitelikli kitaplarla karşılaştırmak, edebiyatın ve dilin özelliklerini kavratabilmek, sezgisel biçimde verebilmek için çocuk edebiyatına ayrı bir değer vermenin gereğini ortaya çıkarmaktadır. Bu nedenle çocuk edebiyatı ürünleri, çocukları nitelikli metinleri yöneltmeyi başarabilen, onlara zamanla okuma kültürü kazandırabilen bir sorumluluk üstlenmelidir (Sever, 2003: 11).

“Çocuk edebiyatı önce edebiyattır. Edebiyat yönü ile edebiyatın içinde en incelikli bir yazarlık biçimidir. Her yaştan okurun ilgisini çekebilen, okunabilen, dili, anlatımı ve biçimi ile edebiyatın içinde yeni bir türdür.” (Şirin, 2000: 10). Edebiyatın oluşumuyla ilgili bütün ilkeler çocuk edebiyatı için de gereklidir. Ancak yetişkin edebiyatından farklıdır. Çünkü çocuk edebiyatı; farklı beceriler, farklı gereksinimler ve farklı okuma biçimleriyle farklı bir hedef kitle için yazılmıştır (Hunt, 2005: 3). Bu nedenle çocuk edebiyatından beklenen; çocuğu biçimlendiren nesne olarak görmeyen, onu birey yerine koyan ve yaşadıklarını, kaygılarını anlatan, kendini anlatabilmesine köprü oluşturabilecek bir işleve sahip olmasıdır (Neydim, 2003: 94). Bu işlevi yerine getirebilmek için nitelikli çocuk kitaplarına gereksinim vardır. Bu kitaplar, çocuklara yazınsal metinlerin ve resmin iletilerini tanıma ve anlamaya dayalı bilişsel ve duyuşsal boyutlu davranışlarını uygulayabileceği, sınayabileceği olanaklar sunmalıdır (Sever, 2003: 11-12). Bunu yaparken aynı zamanda çocukta okuma keyfi yaratan, çocuğa düşleme, esinlenme ve farklı deneyimler yaşama olanağı sunan, usavurma yetisi kazandıran, yazınsal ve güzelduyusal seçenekler yaratan ve çocuğun anlayış ve özdeşleyim duygusunu geliştiren, nitelikte olmalıdır (Lynch-Brown ve Tomlinson, 1999: 3-4). Ayrıca çocuk kitapları, çocuğun dil dağarcığındaki sözcük sayısına uygun, kavrayabileceği tümce yapısında ve anlayabileceği anlatım biçiminde olmalıdır (Kantarcıoğlu, 1991: 13). Aynı zamanda kitap çocuğun duyuş ve düşünüşteki sentez yetisine ilişkin bir bilimsellik içermelidir. Çünkü çocuğun yazınla tanışmasında, duyma-düşünme sorumluluğu edinmesinde ve okuryazar olmasında çocuk yazını önemli bir rol oynamaktadır. Bütün bunlar ise çocuk edebiyatını farklı yönleriyle irdelemek gereğini ortaya çıkarmaktadır. Bu bağlamda, alanyazındaki çocuk edebiyatı alanındaki tezler üzerine içeriğe yönelik çalışmalar yapılması gerekmektedir.

Yazın eğitiminin önemli bir aracı olarak çocuk ve gençlik kitapları, çocuklara yazın bilinci kazandırma işlevine sahiptir. Bir başka deyişle, nitelikli çocuk kitapları çocuklara yazın ile hesaplaşabilme olanağının kapılarını açan bir geçiş yazınıdır (Dilidüzgün, 2003). $\mathrm{Bu}$ nedenle çocuk yazını ürünleri ve çocuk yazını üzerine yapılan çalışmalar; çocuklara uygulama, kendini sınama ve duyma-düşünme sorumluluğu vermesi açısından önemli bir gerçeklik sunmakta ve bu gerçeklik yönüyle de önem taşımaktadır. 


\section{Alanyazın taramasi}

Günümüzdeki eğitim alanındaki gelişmelere koşut olarak bilimsel araştırmaların sayısı giderek artmaktadır. Bu noktada, çalışmaların niteliğinin sorgulanması gereği ortaya çıkmaktadır. Türkçe eğitimi alanına dönük olarak alanyazında belli açılardan akademik çalışmalar üzerine inceleme yapıldığı görülmektedir: Türkçenin eğitimi-öğretimi alanındaki yüksek lisans ve doktora tezleri, uluslararası bilimsel toplantılardaki bildiriler, makaleler (Sevim ve İşcan, 2012; Sevim ve Özdemir Erem, 2012; Şahin, Kana ve Varışoğlu, 2013; Varışoğlu, Şahin ve Göktaş, 2013; Aktaş ve Uzuner Yurt, 2015; Bozkurt ve Uzun, 2015; Boyac1 ve Demirkol,2018; Turan, Sevim ve Tunagür, 2018), dil öğretiminde yöntem (Eski, 2019), dinleme becerisi (Doğan ve Özçakmak, 2014), e-kitap (Alpkıray ve Samur, 2018), eleştirel okuma (Çam Aktaş, 2015), görsel okuryazarlık (Tanrıverdi ve Apak, 2013), konuşma becerisi (Potur ve Yıldız, 2016; Alver ve Taştemir, 2017), medya okuryazarlığı (Erdem, 2018), okuma becerisi (Akaydın ve Çeçen, 2015; Ceran, Aydın ve Onarıcıoğlu, 2018; Değirmenci Gündoğmuş, 2018; Özdemir, 2018; Yıldız, Çoban Sural ve Boz, 2019), şiir (Şeref, 2019), Türk dili ve edebiyatı eğitimi (Veyis, 2020), yabancılara Türkçe öğretimi (Büyükikiz, 2014; Biçer, 2017; Küçük ve Kaya, 2018; Türkben, 2018) ve yazma eğitimi (Tok ve Potur, 2015).

Türkiye'de çocuk edebiyatı üzerine yapılan ulusal tezlerle ilgili birçok çalışma bulunmaktadır. Gürel ve Şimşek (2005) ile Altunya (2012), Türk çocuk edebiyatı üzerine bir kaynakça oluşturmuştur. Gürel ve Şimşek'in (2005) çocuk edebiyatı konusunda hazırladıkları bibliyografyada 230 tez yer almaktadır. Altunya (2012), 1974-2011 yılları arasındaki yüksek lisans doktora ve doçentlik tezlerini yıl sıralaması bağlamında ele almıştır. Coşkun, Özçakmak ve Balcı'nın (2011) çalışmasında ise Türkçe eğitimindeki eğilimler üzerinde durulmuş; 1981-2010 yılları arasında çocuk edebiyatı alanıyla ilgili 233 lisansüstü tez belirlenmiştir. Balcı (2012) çalışmasında, 1981-2010 yılları arasında çocuk edebiyatı konusunda hazırlanan lisansüstü (267 tez) tezleri tür, hazırlanma dönemi ve konularına göre sınıflandırıp değerlendirmiştir. Yazıcı (2013), YÖK veri tabanından ulaştığı 249 tezi; konu, tür, bilim dalı gibi birçok açıdan incelemiştir. Fidan (2019), çocuk edebiyatı eserlerini değerler eğitimi yönünden inceleyen lisansüstü tezleri değerlendirmiştir. Balta (2019), 2011-2018 yılları arasındaki çocuk edebiyatı üzerine yapılmış 278 tezi; Ertekin ve Çamlıbel Çakmak (2019), okulöncesi döneme seslenen resimli çocuk kitaplarına dönük 56 lisansüstü tezi incelemiştir. Ancak yapılan çalışmalara bakıldığında, ulusal düzeydeki tezlerle sınırlı kaldığı ve uluslararası alandaki tezlerle karşılaştırmalı bir biçimde değerlendirme yapılmadığı görülmektedir. Bu çalışmanın hem ulusal hem de uluslararası tezleri bir arada ele alması yönüyle araştırmacılara 1şık tutacağı düşünülmektedir.

Çocuk edebiyatı ile ilgili çalışmak isteyenler için çocuk edebiyatına yönelik araştırmalardaki eğilimleri (konu, araştırma yöntemi, veri toplama araçları, vb.) belirlemede kaynak oluşturabilecek çalışmalara gereksinim duyulmaktadır. Bu nedenle bu çalışmanın amacı, çocuk edebiyatına ilişkin ulusal ve uluslararası tezleri araştırma konuları, araştırma desenleri, veri toplama araçları, vb. açısından karşılaştırmaktır. Bu temel amaç doğrultusunda şu sorulara yanıt aranmıştır: 
1. 2010-2019 yılları arasında yayımlanan ulusal ve uluslararası tezlerin cinsiyet dağ 11 ımı nedir?

2. Ulusal ve uluslararası tezlerin yıllara göre dağılımı nedir?

3. Ulusal ve uluslararası tezlerin lisansüstü düzey dağılımları nedir?

4. Ulusal ve uluslararası tezlerde hangi araştırma desenleri kullanılmaktadır?

5. Ulusal ve uluslararası tezlerde hangi veri toplama araçları kullanılmaktadır?

6. Ulusal ve uluslararası tezlerde hangi çalışma grupları/örneklem birimleri üzerinde çalışılmaktadır?

7. Ulusal ve uluslararası tezlerin araştırma konuları nedir?

\section{Yöntem}

\section{Araştırma deseni ve yayın etiği}

$\mathrm{Bu}$ araştırma, betimsel tarama modelinde bir araştırmadır. Betimsel araştırmalarda "ele alınan olaylar ve durumlar, ayrıntılı bir biçimde araştırılmakta, daha önceki olaylar ve durumlarla ilişkisi incelenerek 'ne' oldukları betimlenmeye çalışılmaktadır (Karakaya, 2014: 59). Betimsel tarama modelinde bilimin gözlem, kaydetme, olaylar arasındaki ilişkileri belirleme ve kontrol edilen değişmez ilkeler üzerinde genellemelere varma nitelikleri söz konusudur. Yani bilimin betimleme işlevi ön plandadır (Yıldırım ve Şimşek, 2006). Araştırmada dört aşamadan oluşmuştur. (i) Betimsel tarama için bir çerçeve oluşturulması: $\mathrm{Bu}$ aşamada araştırmanın kavramsal çerçevesinden yola çıkılarak veri analizi için bir çerçeve oluşturulmuştur. Böylece verilerin hangi temaların altında sunulacağı belirlenmiştir. (ii) Verilerin işlenmesi: $\mathrm{Bu}$ aşamada, bir önceki aşamada oluşturulan genel çerçeveye göre elde edilen tarama verileri okunarak düzenlenmiştir. (iii) Bulguların tanımlanması: Bu aşamada düzenlenen verilerin tanımlanması ve gerekli olan yerlere maddeler halinde belirtilmiştir. (iv) Bulguların yorumlanması: $\mathrm{Bu}$ aşamada tanımlanan bulguların açıklanması, ilişkilendirilmesi ve açıklanması yapılmıştır. Yapılan bu çalışmada da YÖK ulusal veri tabanı ve ProQuest uluslararası tez veri tabanında yer alan, 2010-2019 yılları arasında yayımlanan tezler çeşitli değişkenler açısından çözümlenerek açıklanmaya çalışılmıştır. Yapılan çalışmada çözümlenen tezlerin 2019 yılı Haziran ayına kadar olması araştırmanın sınırlılığını oluşturmaktadır.

\section{Verilerin toplanması ve çözümlenmesi}

Araştırmada verilerin toplanmasında "çocuk", "edebiyat" "çocuk edebiyatı", "çocuk yazını" anahtar sözcükleri kullanılmıştır. Ardından şu ölçütler çerçevesinde veriler toplanmıştır: a) YÖK ulusal tez veri tabanı ve ProQuest veri tabanında ulaşılabilir olması, b) çocuk edebiyatına ilişkin olması, c) 2010-2019 (01.01.2010-30.06.2019) yılları arasında yapılmış olması, d) yüksek lisans ve doktora tezleri olması. Bu ölçütler kullanılarak ulusal veri tabanında 220 teze, uluslararası veri tabanından toplam 209 teze ulaşılmıştır. Uluslararası tezlerde dil sınırlamasının İngilizce tutulması ve bazı tezlerin birkaç kez yinelenmesi nedeniyle sayı 289 tezden 209'a düşmüştür. 
Verilerin çözümlenmesinde içerik analizinden yararlanılmıştır. İçerik analizi; amaçların belirlenmesi, konu ile ilgili verilerin yerlerinin belirlenmesi, mantıksal bir yapının geliştirilmesi, kodlama ulamlarının belirlenmesi, sayısallaştırma ve yorumlama basamaklarından oluşmaktadır (Büyüköztürk, vd., 2016: 252-255). İlk olarak, her bir çalışmanın ilgili amacı içerip içermediği, ardından çalışmaların yer alacağı ölçütler belirlendi. Bunun için öncelikle alanyazında tez ve makalelerin içerik çözümlemesine dönük araştırmalar ve bu araştırmalarda kullanılan formlar incelendi (Sözbilir, Kutu ve Yaşar, 2012; Kurt ve Erdoğan, 2015).

\section{Uygulama süreci}

$\mathrm{Bu}$ çalışmalardan yola çıkılarak çocuk edebiyatı alanında yapılan araştırmaların tamamını kapsayacak biçimde bir form düzenlenmiştir. Bu form, tezlerin ve araştırmacının kimliğine ilişkin tanımlayıcı bilgileri, tezlerdeki araştırma desen/yöntemleri ve konu alanını içeren on bir başlıktan oluşmaktadır (Tablo 1):

Tablo 1. Ulusal ve Uluslararası Tezleri İnceleme Başlıkları

Tezin Adı ve Numarası

Tezin Yapıldığı Yer (Yurtiçi, yurtdışı)

Tezin Kabul Yilı

Araştırmacı Cinsiyeti (Kadın, erkek)

Lisansüstü Düzeyi (Yüksek lisans, doktora)

Araştırma Konusu

Veri Toplama Aracı (Gözlem, görüşme, doküman analizi, anket, test, ölçek, ders geçme notu, diğer)

Çalışma Grubu/Örneklem (Öğrenciler, öğretmen adayları, Türkçe öğretmenleri, sınıf öğretmenleri, basılı materyaller, diğer)

Araştırma Konusu

Tezlerin çözümlenmesine ilişkin bir form belirlenerek mantıksal bir yapı oluşturduktan sonra formda yer alan her bir başlık doğrultusunda tezlerin içerikleri kodlanmaya başlandı. Ardından araştırmanın geçerliğini sağlamak için, kodlamalara başlamadan önce de bir ortak kodlama oturumu yapıldı, ardından tezleri paylaşarak belirlenen ulamlar doğrultusunda kodlama yapıldı. Daha sonra ikinci bir oturum gerçekleşti ve kodlamalar arasındaki tutarlığa bakıldı. Her bir araştırmacı, rastlantısal bir biçimde seçilen tezlerin \%20'sini yeniden kodladı. Bu kodlamalardaki iç tutarlılı̆̆ sağlamak amacıyla yapılan bu uygulamada kodlamalar arasındaki uyum hesaplandı. Miles ve Huberman'ın (1994) güvenirlik formülü kullanılarak yapılan hesaplamalarda bu uyum yüzdesi \%90 olarak belirlenmiştir. Elde edilen bulguların sayısallaştırılarak yorumlanması da içerik çözümlemesinin son basamağını oluşturmuştur.

\section{Bulgular}

\section{Tezlerin cinsiyete göre dağılımı}

Araştırmacıların cinsiyetlere göre dağılımına Şekil 1'de yer verilmiştir. Şekil 1'de de görüldügüü üzere, hem ulusal hem de uluslararası tezlerde kadın araştırmacılar, dağılımın yarısından fazlasını oluşturmaktadır. 
Şekil 1. Ulusal ve Uluslararası Tezlerin Cinsiyet Dağılımları
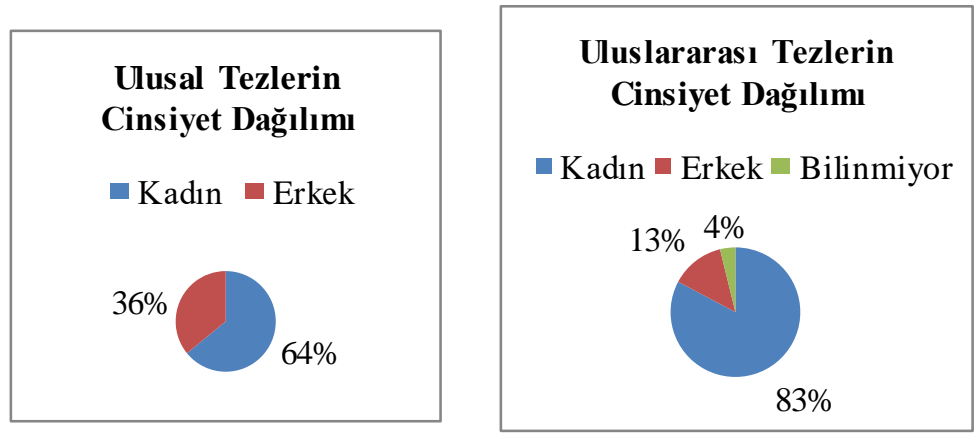

Ulusal tezlerin \%64'ü kadın araştırmacılar tarafından, \%36'sı erkek araştırmacılar tarafından yapılmıştır. Uluslararası tezlerde de benzer biçimde kadın araştırmacılar öne çıkmaktadır. Kadın araştırmacıların oranı \%83 iken erkek araştırmacılar \%13 oranındadır. Bununla birlikte uluslararası tezlerde araştırmacıların \%4'ünün cinsiyet bilgisine ulaşılamamıştır. Tezler içerisinde özgeçmişe yer verilmediği için teşekkür bölümüne bakılmış; bu bölümde de cinsiyetlerine ilişkin herhangi bir yansıtıcı ifadeye rastlanmamıştır. Örneğin; Eşlere yönelik teşekkür durumunda "wife" ya da "husband" ifadesi bir ön bilgi sağlamaktadır. Araştırmacının bilgisunar veri tabanından yola çıkılarak bu bilgilerin doğruluğu da aranmıştır. Ancak bunun dışında kalanlar arasında her ne kadar arama yapılsa dahi araştırmacının bilgisine ulaşılamama durumunda "bilinmiyor" diye belirtilmiştir.

\section{Tezlerin yayımlanma yıllarına göre dağılımı}

Araştırmaların yayımlanma yılına göre dağılımına Şekil 2'de yer verilmiştir. Ulusal ve uluslararası tezlerin 2010'dan 2019'a kadar dengeli bir dağılım göstermediği görülmektedir:

Şekil 2. Yıllara Göre Ulusal ve Uluslararası Tezlerin Dağılımı
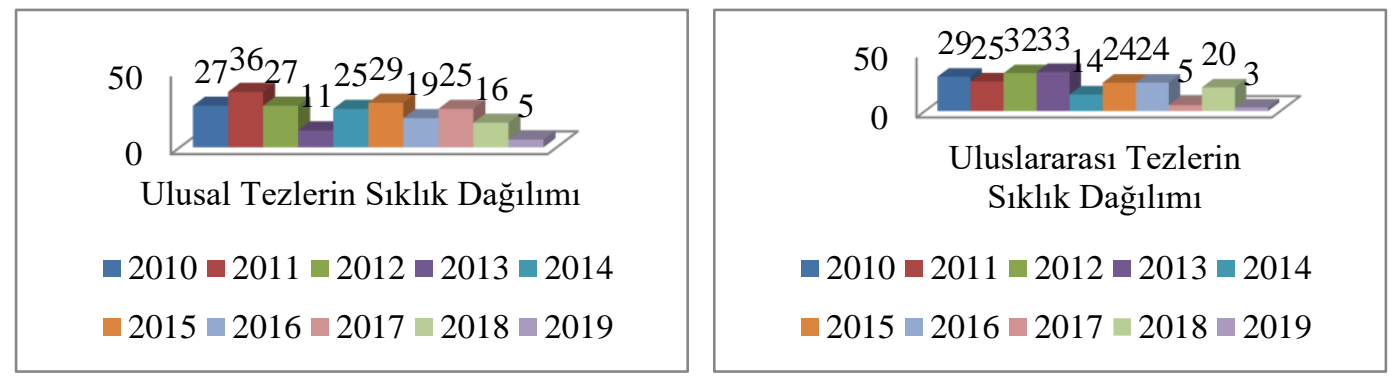

Ulusal tezlerin yıllara göre dağılımına bakıldığında, en çok 2011 yılında yapıldığ 1 belirlenmiştir (f:36). Bunu sırasıyla 2015 (f:29), 2010 ve 2012 (f:27), 2014 ve 2017 (f:25), 2016 (f:19), 2018 (f:16), 2013 (f:11) ve 2019 (f.5) y1llar1 izlemektedir. 2019 y1l, haziran ayına kadar olan tezlerin ele alınması nedeniyle sayı açısından en son sırada yer almaktadır. Ancak 2013 yılında diğer yıllara oranla çok daha az çalışma yapıldığ görülmektedir.

Uluslararası tezlerin yıllara göre dağılımında ise 2013 (f:33) ve 2012 (f:32) yılları öne çıkmaktadır. Bu oranları, 2010 (f:29), 2011 (f:25), 2015 ve 2016 (f:24), 2018 (f.20), 2014 (f:14), 2017 (f:5) ve 2019 (f.3) yılları izlemektedir. 2019 yılı, ulusal tezlerde olduğu 
gibi haziran aynının sonuna kadar tezlerin ele alınması nedeniyle en son sirada yer almaktadır. Ancak 2017 yılında yalnızca 5 tezin olması, diğer tüm yıllara oranla bu yılda "çocuk edebiyatı" alanında tezlerin en az yapıldığının bir göstergesidir. 2014 yılında ise 2013 yılına oranla yaklaşık \%40 oranında bir azalma belirlenmiştir.

\section{Tezlerin lisansüstü düzeylerine göre dağılımı}

Şekil 3'te lisansüstü düzeylere göre tezlerin dağılımı yer almaktadır. Bu bağlamda ulusal ve uluslararası tezlerin dağılımındaki farklılık göze çarpmaktadır:

Şekil 3. Ulusal ve Uluslararası Tezlerin Lisansüstü Düzeye Göre Dağılımı
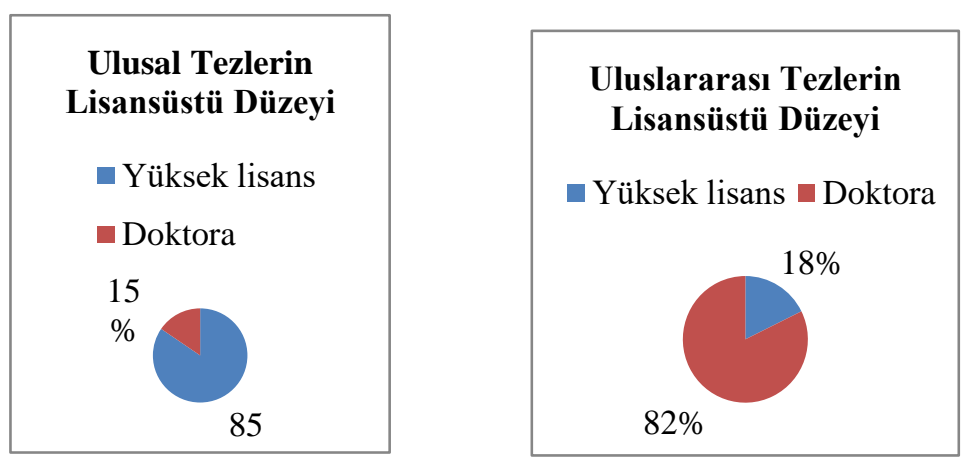

Ulusal tezlerin $\% 85$ 'i yüksek lisans düzeyinde iken $\% 15$ 'i doktora düzeyinde yapılmıştır. Ancak uluslararası tezlerde bu durum tam bir koşutluk göstermektedir. \%18'i yüksek lisans düzey ve \%82'si doktora düzeyindedir. Çocuk edebiyatı alanında ulusal tezlerde yüksek lisans çalışmaları ağırlıklı iken uluslararası tezlerde doktora düzeyi ön plandadir.

\section{Tezlerin araştırma deseni ve veri toplama araçlarına göre dağılımı}

Temel aldıkları felsefeye, bakış açısında göre nitel ve nicel olmak üzere araştırmalar iki açıdan sınıflandırılmaktadır (Büyüköztürk, vd., 2016, s.12). Karma yöntemin ise nicel ve nitel yaklaşım, yöntem ve kavramların bir bileşkesi olması nedeniyle araştırma desenleri 3 bağlamda ele alınıp incelenmiştir. Ulusal ve uluslararası tezlerin yöntem özellikleri Tablo 2'de ele alınmıştır:

Tablo 2. Ulusal ve Uluslararası Tezlerin Araştırma Desenleri

\begin{tabular}{|c|c|c|c|c|}
\hline \multirow{4}{*}{ 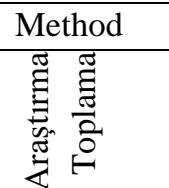 } & & & Çalışmaların Sıklığ & $\%$ \\
\hline & \multirow[t]{3}{*}{ Nitel } & Görüşme & 7 & $\% 3.19$ \\
\hline & & Gözlem & - & $\% 0$ \\
\hline & & İçerik analizi & 168 & $\% 76.36$ \\
\hline \multirow{3}{*}{ 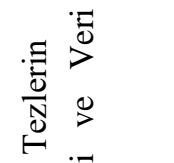 } & \multirow[t]{3}{*}{ Nicel } & Anket & 8 & $\% 3.64$ \\
\hline & & Ölçek & - & $\% 0$ \\
\hline & & Test & 4 & $\% 1.82$ \\
\hline \multirow{3}{*}{ 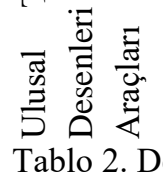 } & \multirow[t]{3}{*}{ Karma } & Nitel+nitel & 16 & $\% 7.27$ \\
\hline & & Nicel+nicel & 3 & $\% 1.36$ \\
\hline & & Nitel+nicel & 14 & $\% 6.36$ \\
\hline \multicolumn{3}{|c|}{ Toplam } & 220 & $\% 100$ \\
\hline
\end{tabular}




\begin{tabular}{|c|c|c|c|c|}
\hline \multirow{3}{*}{ 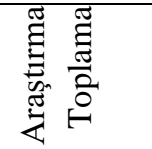 } & \multirow[t]{3}{*}{ Nitel } & Görüşme & 4 & $\% 1.91$ \\
\hline & & Gözlem & - & $\% 0$ \\
\hline & & İçerik analizi & 153 & $\% 73.21$ \\
\hline \multirow{3}{*}{ 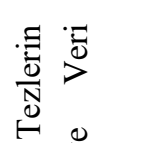 } & \multirow[t]{4}{*}{ Nicel } & Anket & - & $\% 0$ \\
\hline & & Ölçek & - & $\% 0$ \\
\hline & & Test & - & $\% 0$ \\
\hline \multirow{4}{*}{ 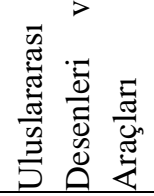 } & & Tarama & 1 & $\% 0.48$ \\
\hline & \multirow[t]{3}{*}{ Karma } & Nitel+nitel & 24 & $\% 11.49$ \\
\hline & & Nicel+nicel & 4 & $\% 1.91$ \\
\hline & & Nitel+nicel & 23 & $\% 11.00$ \\
\hline Toplam & & & 209 & $\% 100$ \\
\hline
\end{tabular}

Öncelikle ulusal tezlere bakıldı ̆̆ında, baskın olarak nitel araştırma deseninden yararlanıldığı belirlenmiştir (f:175, \%79.55). Nitel araştırma desenine bağlı olarak sıklıkla alanyazın taramadan yararlanılmış ve tarama verileri içerik analizi ile elde edilmiştir. Uluslararası tezlerde ise bu oran \%75.12'dir ve ulusal tezlerde olduğu gibi betimsel çözümleme ağırlıklı olarak çalışılmıştır. Bununla birlikte bu çalışmalar arasından 36 ulusal tezde, 105 uluslararası tezde hangi yöntemin kullanıldığı açık bir biçimde belirtilmemiştir. Anacak bu tezler incelendiğinde doküman incelemesi yoluyla içerik analizinin yapıldı̆̆ 1 belirlenmiştir. Bu tezlerin edebiyat alanındaki anabilim dallarında yürütülen tezler olması ise bir başka dikkat çekici yöndür. Çünkü eğitim bilimleri alanlarındaki tezlerde yöntem başlığının ayrı bir biçimde ele alınması gözetilmiş, bu sayede araştırmaların yöntemleri ve veri toplama araçlarına doğrudan ulaşılmıştır.

Nitel araştırma yöntemlerinden gözlem ayrı ve bağımsız bir yöntem olarak ele alınmamış; karma yöntem içinde nicel yöntemlerin biriyle ilişkilendirilmiştir. Görüşme yönteminin bağımsız olarak işe koşulduğu tezlerin (ulusal f:7; uluslararası f:4) yanı sıra karma yöntemde görüşme sıklıkla başvurulan nitel araştırma yöntemleri arasındadır.

Nicel araştırma yöntemleri içinde deneysel araştırmalara daha çok yer verilmiştir. Ulusal tezlerde 12, uluslararası tezlerde ise 5 araştırmada deneysel araştırma desenlerinden yararlanılmıştır. Yalnızca anket ya da testin veri toplama aracı olarak işe koşulduğu araştırmalar, ulusal tezlerde görülmektedir. Uluslararası tezlerde ise karma yöntemlerde kullanılmış ve bu yöntemleri nitel ya da nicel başka bir yöntemle ilişkilendirerek ele almak yeğlenmiştir.

Karma araştırma deseninden ulusal tezlerde yaklaşık \%15 oranında, uluslararası tezlerde ise yaklaşık \%25 oranında yararlanılmıştır. Morse’ye (2003) göre karma araştırma tasarımları, nitel ve nicel yöntemlerin sıralı ve baskın olma durumuna göre sunulabilir ve eşzamanlı ya da sıralı karma yöntem araştırmalarında yöntemler, nicel ya da nitel paradigmalar içerisinde birleşebilmektedir (Baki ve Gökçek, 2012, s.10-11). Bu nedenle tezlerle ilgili yapılan incelemelerde, nitel ve nicel araştırmaların bileşke tasarımının yanı sıra nitel ve nitel ya da nicel ve nicel araştırma tasarımlarının yeğlendiği de belirlenmiştir. $\mathrm{Bu}$ nedenle üç yönlü olarak sınıflanıdırılmıştır: nitel+nitel, nicel+nicel ve nitel+nicel. Gerek ulusal gerekse uluslararası tezlerde en az nicel+nicel araştırma tasarımına yer verilmiştir. Nitel+nitel araştırma tasarımı, nitel+nicel araştırma tasarımına göre çok az bir 
farkla öne çıkmaktadır. Ulusal tezlerde bu fark \%0.91 iken uluslararası tezlerde \%0.49'dur. $\mathrm{Bu}$ nedenle bu iki tasarımın benzer oranlarda işe koşulduğu söylenebilir.

Ulusal ve uluslararası tezlerdeki araştırma desen ve yöntemlerindeki farklılaşmalar, veri toplama araçlarına da yansımıştır. Özellikle karma araştırma desen/yöntemin işe koşulması ile birlikte veri toplama araçlarının sayısı, toplam tez sayısı ile farklılık göstermektedir.

Şekil 4. Ulusal ve Uluslararası Tezlerdeki Veri Toplama Araçları
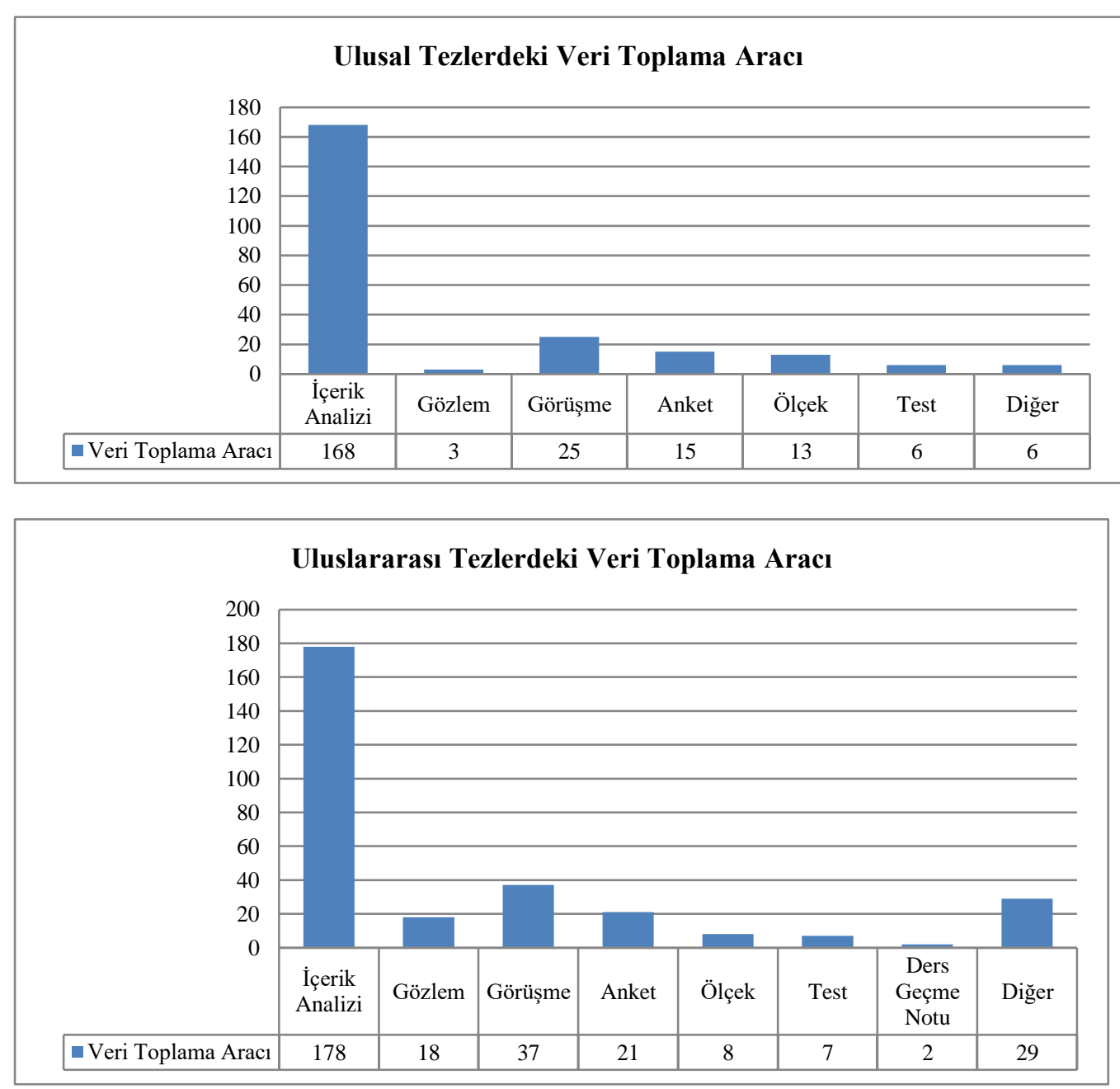

Şekil 4'te de görüldüğg̈ üzere, veri toplama aracı olarak her iki grafikte içerik analizi öne çıkmaktadır. Ulusal tezler ile uluslararası tezlerin sıklık oranlarının benzer olduğu görülmektedir (Ulusal-f:168; Uluslararası-f:178). Bu durumu sırasıyla görüşme ve anket izlemektedir. Ulusal tezlerde görüşme 25, anket $15 \mathrm{kez}$ işe koşulurken uluslararası tezlerde görüşmeden 37, anketten ise $21 \mathrm{kez}$ yararlanıldığ 1 belirlenmiştir. Ancak bu siralamayı ulusal tezlerde ölçek, test ve gözlem izlerken uluslararası tezlerde gözlem, ölçek, test ve ders geçme notu izlemektedir. Ölçek ve testten yararlanma açısından toplam sayı yönüyle ulusal ve uluslararası tezlerde büyük bir oranda farklılaşma görülmemiştir (Ulusal- $\sum$ f: 19; Uluslararası- $\sum$ f:15). Ancak bu durum, gözlemde oldukça farklıdır. Ulusal tezlere oranla uluslararası tezlerde gözlemin daha çok işe koşulduğu söylenebilir. Uluslararası tezlerde, ders geçme notunun da veri toplama aracı olarak kullanılması dikkat çekicidir. Ayrıca video ve ses kaydı ile sesli okuma hızı kayıtları, metni anlamaya dönük 
verilen yanıtlar, çocukların romana ilişkin çizdiği resimler, günlük ve yansıtıcı günlük, dijital kayıtlar, web analizi, alan notları, araştırmacı notları, video kaydı, tartışma kayıtları, raporlar, seyir defteri-eğitim tutanağı, fotoğraflar, skeçler, kitap seçim prosedürleri, dijital yazışma kayıtları gibi çok yönlü araçlara da başvurulmuştur. Ulusal tezlerde ise "diğer" adı altında verilen oran, metin değerlendirmeye dönük formları ve künye formlarını yansıtmaktadır. $\mathrm{Bu}$ açıdan bakıldığında, uluslararası tezler veri toplama araçlarındaki farklılaşma yönünden öne çıkmaktadır.

\section{Tezlerdeki çalışma grubu/örneklem birimlerinin dağılımı}

Ulusal ve uluslararası tezlerde çalışma grubunu/örneklemini "öğrenci, öğretmen adayları, öğretmenler, basılı materyaller ve diğer" ulamları oluşturulmuştur. "Öğrenci" ulamı, okulöncesinden yükseköğretime kadar her düzeydeki öğrencileri kapsamaktadır. Ancak yükseköğretim öğrencileri arasında öğretmen adayları ile çalışıldıysa bu grup ayrı bir ulamda ele alınmıştır. Öğretmen adayları kapsamında okulöncesi öğretmenliği, Türkçe, İngilizce gibi dil derslerinin öğretmenliği ve matematik öğretmenliği gibi alanlardaki öğrenciler yer almaktadır. Basılı materyaller içerisinde kitapların yanı sıra dergiler ve gazetelerle ilgili yapılan çalışmalar da bulunmaktadır. Ulusal ve uluslararası tezlerin çalışma grubu dağılımına Şekil 5'te yer verilmiştir.

Şekil 5. Ulusal ve Uluslararası Tezlerdeki Çalışma Grubu

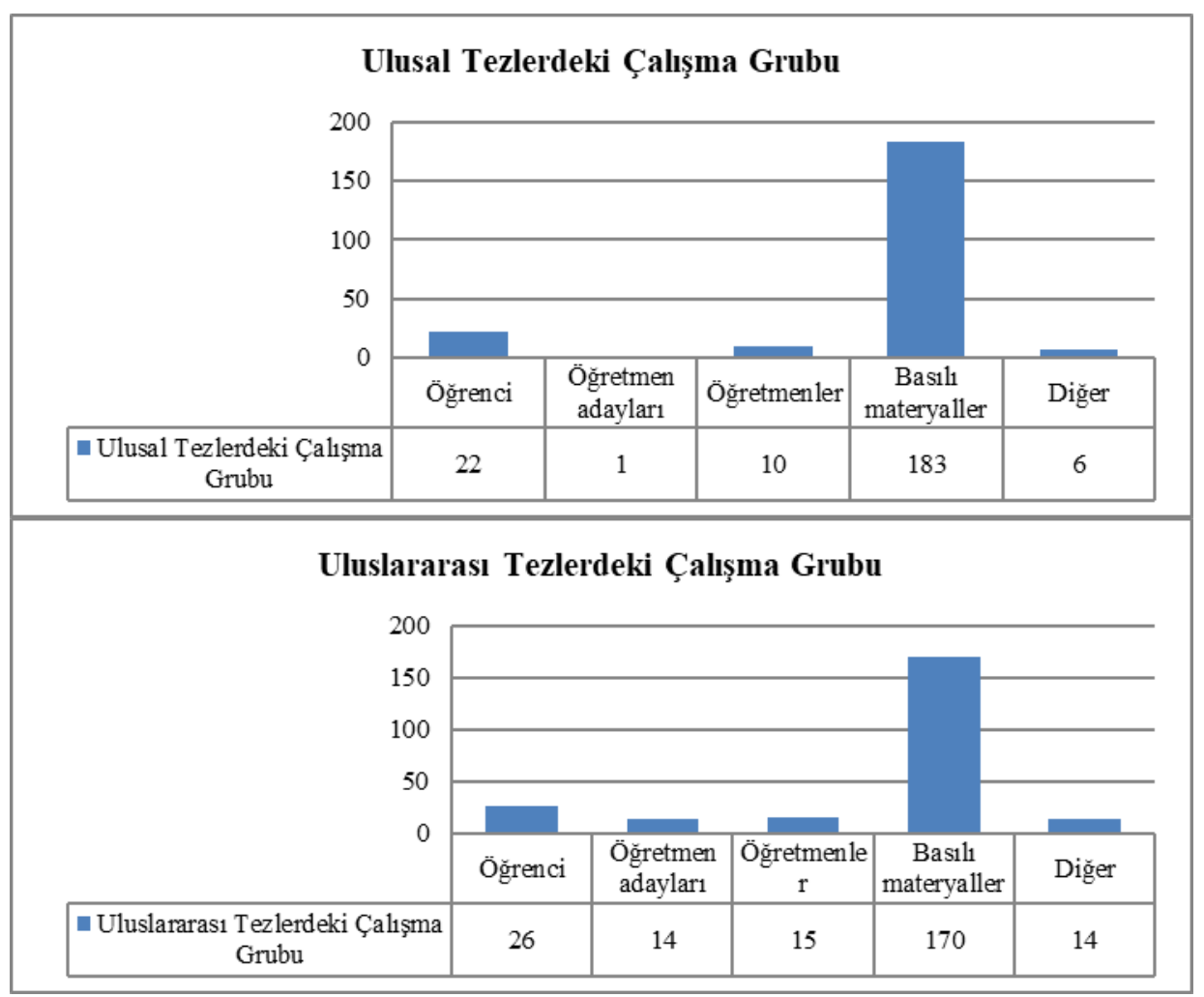

Şekil 5'e bakıldığında, ulusal ve uluslararası tezlerin her ikisinde de en çok basılı materyaller üzerinde çalışıldığı belirlenmiştir. Ulusal tezlerin 183'ünde, uluslararası tezlerin ise 170 'inde basılı materyallerden yararlanılmıştır. Bunu öğrencilerle yapılan çalışmalar izlemektedir. 22 ulusal ve 26 uluslararası tezin çalışma grubunu öğrenciler oluşturmaktadır. Her ikisinde de farklı öğrenim düzeyindeki öğrencilerle çalışılmıştır. Örneğin; uluslararası tezlere bakıldığında, 3 tezde okulöncesi öğrencisi,14 tezde ilkokul 
öğrencisi, 5 tezde ortaokul öğrencisi, 2 tezde lise öğrencisi ve 2 tezde yükseköğretim öğrencisi (öğretmen adayı dışındaki çalışma grubu) ile çalışıldığı belirlenmiştir. Bir diğer çalışma grubu olan öğretmenlerle çalışma yapan uluslararası tez sayısı 15 iken ulusal tez 10 'dur. Sıklık açısından öğretmenlerle yapılan çalışmaların benzer oranda olmasına karşın öğretmen adayları ile yapılan çalışmalar arasında önemli oranda bir farklılaşma vardır. Ulusal tezlerde yalnızca 1 tezde öğretmen adayları ile çalışıldığı belirlenmişken uluslararası tezlerde 14'tür. Uluslararası tezlerdeki bu sıklık oranı, öğretmenlerle yapılan çalışma oranı ile benzerlik göstermektedir (Öğretmenler $\sum \mathrm{f}$ : 15; Öğretmen adayları$\left.\sum \mathrm{f}: 14\right)$. Ulusal tezlerde çalışma grubu olarak ayrıca sözlü materyallerden de yararlanılmıştır (f:6). Uluslararası tezlerde ise farklı çalışma grupları dikkat çekmektedir: anadili Japonca ve İngilizce olan bireyler, psikolog, haham ve sosyal hizmet uzman1, yazar, çizer, eleştirmen ve yayınevi sahipleri, veliler, okul müdürleri ve danışmanlar, blog, sergi, medya ve okuma uzman1, vb.

\section{Tezlerdeki çalışma konularının dağılımı}

Çalışma konularının ulusal ve uluslararası tezlerdeki ortak olan yönleri ile farklılıklarına Tablo 3'te yer verilmiştir.

Tablo 3. Ulusal ve Uluslararası Tezlerin Genel Konu Başlıkları

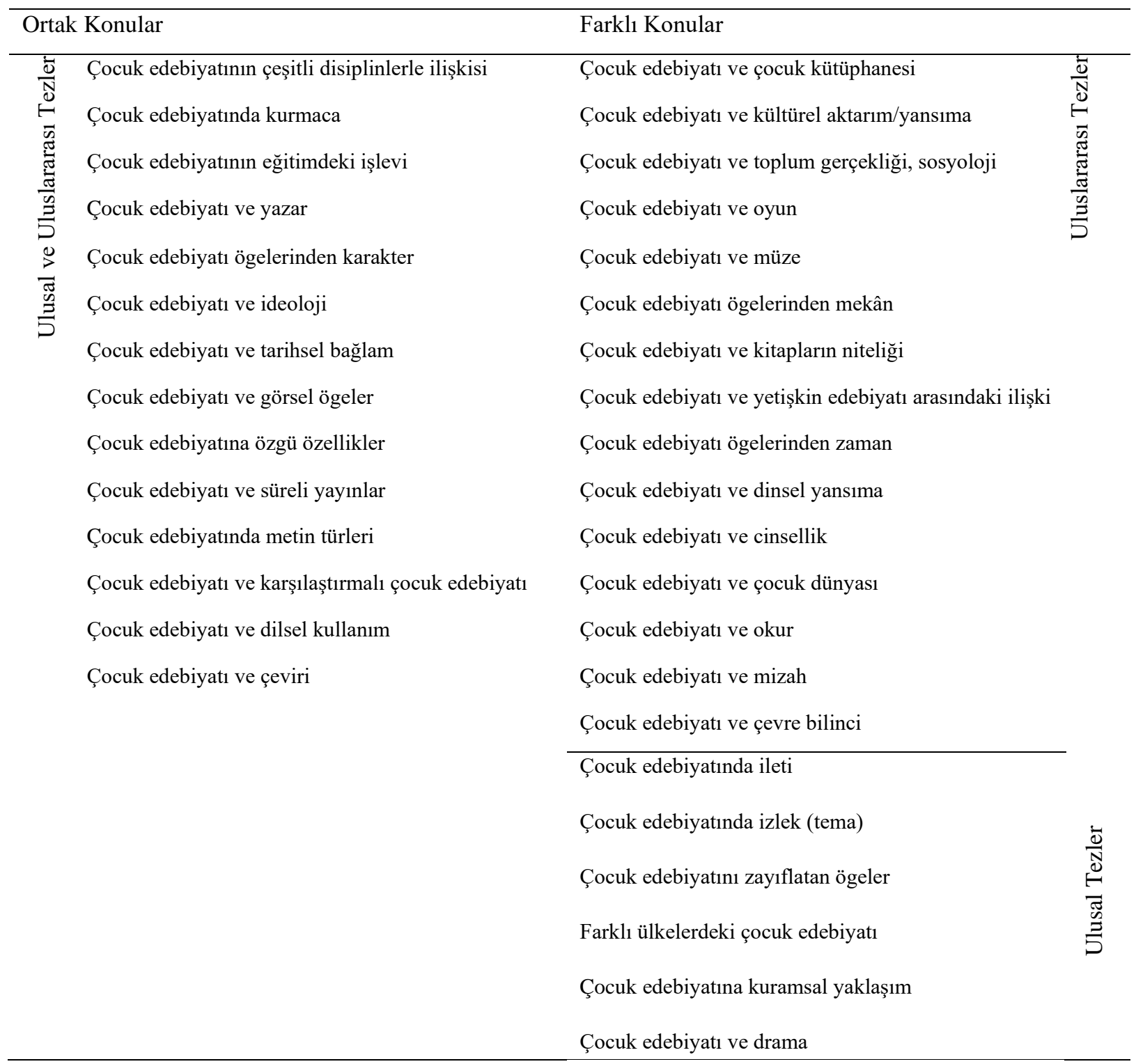


Tablo 3'e bakıldığında, 14 konu alanı açısından ulusal ve uluslararası tezlerin benzerlik göstermesine karşın 21 konu alanında ayrımlaştığ görülmektedir. Bu farklılıklar yönüyle ulusal tezlere oranla (f: 6) uluslararası tezler daha çok öne çıkmaktadır (f:15). Bu açıdan uluslararası tezlerin çocuk edebiyatını ele aldığı konuların dağılımı $\sum$ f: 29 iken ulusal tezlerde $\sum$ f: 20 'dir.

Şekil 6.1. Ulusal Tezlerin Konu Dağılımı
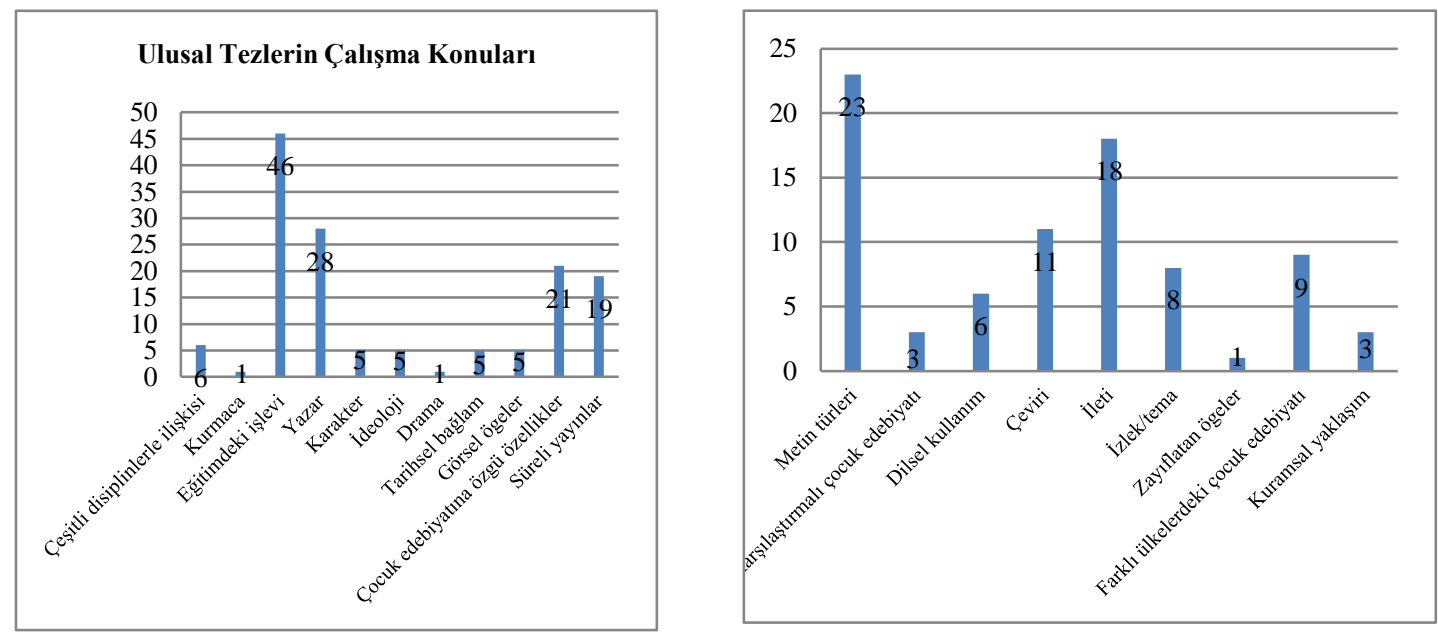

Ulusal ve uluslararası tezlerin konu dağılım sıklıklarına Şekil 6.1 ve Şekil 6.2'de yer verilmiştir. Şekil 6.1'e bakıldığında, ulusal tezlerde en çok çocuk edebiyatının eğitimdeki işlevine yer verildiği görülmektedir (f:46). Bunu çocuk edebiyatı yazarları ile ilgili araştırmalar (f:28) ve çocuk edebiyatındaki metin türleri (f:23) izlemektedir. Ardından sırasıyla şu konular ele alınmıştır: çocuk edebiyatına özgü özellikler (f:21), süreli yayınlar (f:19), ileti (f:18), çeviri çocuk edebiyatı (f:11), farklı ülkelerdeki çocuk edebiyatı (f:9), izlek (f:8), çeşitli disiplinlerle ilişkisi ve dilsel kullanım (f:6), karakter, ideoloji, tarihsel bağlam ve görsel ögeler (f:5), kuramsal yaklaşım ve karşılaştırmalı çocuk edebiyatı (f:3), kurmaca, drama ve zayıflatan ögeler (f:1).

Şekil 6.2. Uluslararası Tezlerin Konu Dağılımı
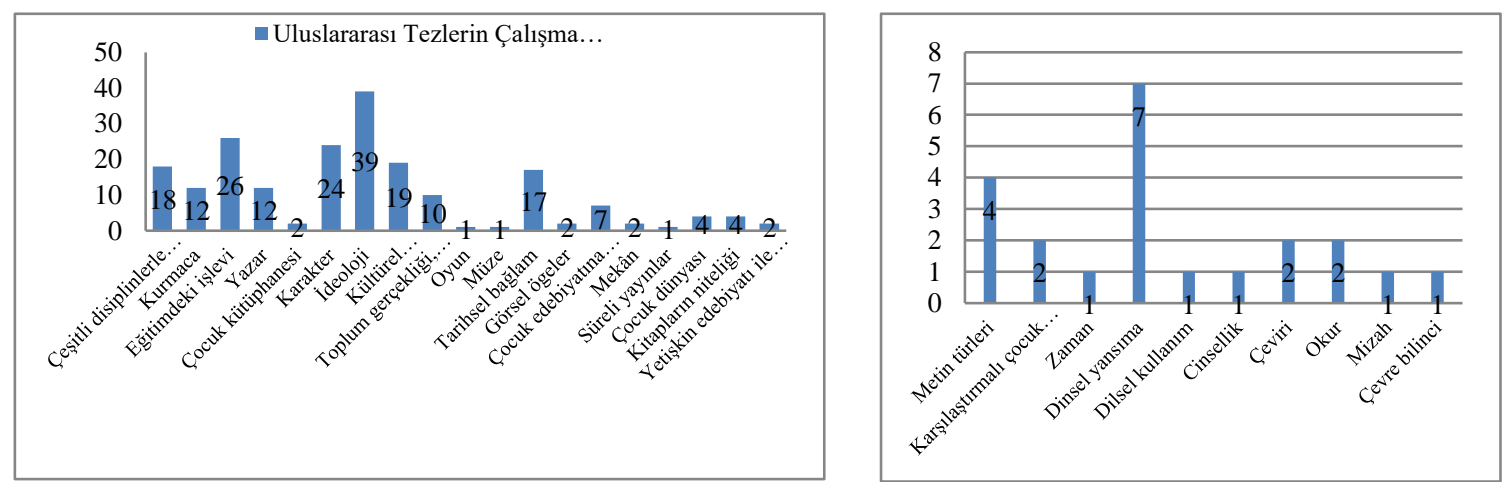

Şekil 6.2'de ise uluslararası tezlerde en çok çocuk edebiyatına ideolojinin yansımaları üzerinde durulduğu görülmektedir (f:39). Çocuk edebiyatının eğitimdeki işlevi ise ikinci sırada yer alan çalışma konusudur (f:26). Çocuk edebiyatının temel ögelerinden biri olan karakter üzerine yapılan çalışmalar da öne çıkanlar arasındadır (f:24). Ardından bunu sırasıyla şu konular izlemektedir: kültürel aktarım/yansıma (f:19), çeşitli disiplinlerle 
ilişkisi (f:18), tarihsel bağlam (f:17), kurmaca ve yazar (f:12), toplum gerçekliği-sosyoloji (f:10), çocuk edebiyatına özgü özellikler ve dinsel yansıma (f:7), çocuk dünyası, kitapların niteliği ve metin türleri (f:4), çocuk kütüphanesi, görsel ögeler, mekân, yetişkin edebiyatı ile arasındaki ilişki, karşılaştırmalı çocuk edebiyatı, çeviri ve okur (f:2), oyun, müze, süreli yayınlar, zaman, dilsel kullanım, cinsellik, mizah ve çevre bilinci (f:1).

Konu dağılımlarının alt alanlarına bakıldığında da farklılıklar göze çarpmaktadır. Çocuk edebiyatının çeşitli disiplinlerle ilişkisinde ulusal tezlerde sosyal bilgiler (f:3), sosyopedagoji (f:1), coğrafya (f:1), sağlık bilimi(engellilik, f:1) alanları öne çıkarken uluslararası tezlerde psikoloji (f:8), medya (f:2), matematik (f:1), müzik (f:1), gazetecilik (f:1), sosyal bilgiler (f:1), felsefe (f:3) ve anlatıbilim (f:1) ile ilişkiyi ele alan çalışmalar yer almaktadır.

Çocuk edebiyatının eğitimdeki işlevine yönelik ulusal tezlerde okuma eğitimi (f:12), değerler eğitimi (f:20), duyuşsal alan eğitimi (empati, liderlik, başarı güdüsü, f:4), dinleme eğitimi (f:2), beslenme eğitimi (f:1), karakter eğitimi (f:2), kavram öğretimi (f:1), yabancı dil öğretimi (f:3) ve anadili öğretimi (f:1) ile çocuk edebiyatının ilişkilendirildiği belirlenmiştir. Uluslararası tezlerde öğretmen eğitimi (f: 4), duyarlık ve ahlak eğitimi (f:2), okuma eğitimi (f: 8), matematik öğretimi (f:4), özel eğitim (f:1), çocuk eğitimi-yetiştirme (f:1), demokrasi eğitimi (f:1), sosyal bilgiler eğitimi (f:1), karakter eğitimi (f:2), program geliştirme (f:1) ve bilim eğitimi (f:1) bağlamında çocuk edebiyatı ele alınmıştır.

İdeoloji ile ilgili çalışmalarda ulusal tezlerde çocuk hakları (f:1), siyaset (f:1) ve cinsiyetçilik (f:3) ele alınırken uluslararası tezlerde bu konu alanındaki çeşitlilik dikkat çekmektedir: siyaset (f:2), feminizm ve kadın imgesi (f:5), cinsiyet rolleri ve algısı (f:3), ayrımcılık ve cinsiyet ayrımcılığı (f:6), $\operatorname{rkç̧ılık~(f:13),~yasaklanan~kitaplar~(f:1),~}$ cumhuriyetçilik (f:1), faşizm (f:1) ve ulusalcılık (f:3).

Uluslararası tezlerde en çok öne çıkanlar arasında yer alan, ancak ulusal tezlerde yer verilmeyen kültürel aktarım ve yansıma bağlamında genelde çokkültürlülük, yerel ve melez kültür karşılaştırmaları üzerinde durulduğu belirlenmiştir. Bir diğer ulusal tezlerde ele alınmayan konu alanı olan toplum gerçekliği ise eşcinsellik, karma 1rk, yerli halk, sosyal sınıf ve mitler bağlamında ele alınmıştır.

Çocuk edebiyatında metin türleri olarak ulusal tezler 23 araştırmayla dikkat çekmektedir: çizgi roman (f:2), şiir (f:1), öykü (f:9), masal/ninni (f:2), roman (f:5), nasihatname (f:2), destan (f:1) ve biyografi (f:1). Uluslararası tezlerde ise birkaç metin türü üzerinde durulmuştur: bilimkurgu (f:1), transmedya metinleri (f:1), şiir (f:1) ve didaktik metinler (f:1). Dinsel yansımanın ise ulusal tezlerde ele alınmaması dikkat çekici. Uluslararası tezlere bakıldığında Yahudilik, Hristiyanlık ve dinsel ideoloji açısından incelemeler yapılmıştır.

Çocuk edebiyatına özgü özellikler, ulusal tezlerde çocuk edebiyatı temel ilkeleri (f:13), çocuğa görelik ve çocuk gerçekliği (f:8) bağlamında ele alınırken uluslararası tezlerde çocuk gerçekliğinin (f:1) yanı sıra çocukluk kavramı ve çocuk imgesi (f:4) ile yaratıc1lık (f:1) üzerinde durulmuştur. Ayrıca çocuk dünyası bağlamında çocuk karakterlerdeki dönem etkisi (f:1), âdet dönemi (f:1), çocuk gereksinimleri (f:1) ve ergenlik kavramına (f:1) da yer verilmiştir. 
Çocuk edebiyatında ileti ve izlek, yalnızca ulusal tezlerde öne çıkmaktadır. Aynı durum, çocuk edebiyatını zayıflatan ögeler, farklı ülkelerdeki çocuk edebiyatı ve çocuk edebiyatına kuramsal yaklaşım açısından da geçerlidir. Farklı ülke ve toplumlardaki çocuk edebiyatı yapıtlarıyla karşılaştırma bağlamında; Kosova (f:2), Makedonya (f:1), Bulgaristan (f:1), İran (f:1), İspanyol (f:1), Irak (f:1) ile Kaşgar Türkleri (f:1) ve Araplar (f:1)'ın dünyasındaki çocuk edebiyatı yapıtlarının incelemesi yapılmıştır.

Çocuk edebiyatında görsel ögeler, ulusal tezlerde resim (f:2), dijital resimleme (f:1) ve tasarım (f:2) bağlamında ele alınırken uluslararası tezlerde bu konu alanı yalnızca 2 çalışma ile sınırlıdır. Çocuk edebiyatının temel ögelerinden biri olan karakterlerin ise ulusal tezlerde yalnızca 5 araştırmada, uluslararası tezlerde ise 24 çalışmada ele alındığ 1 belirlenmiştir. Uluslararası tezlerde karakterler birçok yönüyle incelenmiş ve değerlendirilmiştir. Bunlardan bazıları şunlardır: erkek, kadın ve çocuk; yetim, kötü, engelli ve kurtarıc1 (kahraman) karakterler, ikincil (yardımcı) karakterler, prenses karakteri, çılgın bilim adamı karakteri, insanlaştırılmış hayvan karakterleri, karakterlerin kişilik ve etnik özellikleri, kimlik arayışı ve inanç durumları, vb.

\section{Tartışma}

Çocuk yazını üzerine yapılan ulusal ve uluslararası tezleri inceleyen bu araştırmada, 2010-2019 yılları arasında 220 ulusal tez ve 209 uluslararası tez olmak üzere toplam 429 tez incelenmiştir. Bu incelemede öncelikle araştırmacıların cinsiyet dağılımına bakılmıştır. Hem ulusal hem de uluslararası tezlerde kadın araştırmacılar, dağılımın yarısından fazlasını oluşturmaktadır. Yıldız'ın (2018) araştırmasında da kadın akademisyenlerin gerek ülkemizde gerekse Amerika'da sosyal alanlara ağırlıklı olarak yöneldiği ve bunun kadrolaşmaya yansıdığı vurgulanmaktadır. Bu açıdan çocuk odaklı edebiyatla ilgili araştırmaların kadın ağırlıklı olma durumunu destekler niteliktedir.

Araştırmanın bir diğer yönü olan tezlerin yıllar içindeki dağılımına bakıldığında ise gerek ulusal gerekse uluslararası tezlerin 2010'dan 2019'a kadar dengeli bir dağılım göstermediği belirlenmiştir. Ulusal tezlerde 2011, uluslararası tezlerde 2013 ve 2012 y1l, en çok tezin yapıldığı yıllardır. Yazıcı'nın (2013) çalışmasında 2010-2012 (Kasım 2012) yılları arasında toplam 76 teze ulaşılmıştır. Bu durum Kasım 2012 ile 31.12.2012 arasında 14 tezin daha sisteme eklendiğinin bir göstergesidir. Üstelik Yazıcı (2013), 2010-2012 yılları arasında yalnızca iki yıllık sürede yazılan tezlerin 2000-2009 yılları arasında çalışılan toplam tezlerin yarısından fazla olduğunu belirlemiştir. Bu araştırmada da yine 2010-2012 yılları arasında 90 tez varken 2013-2019 (Haziran) arasında 130 tez olduğu, buna göre 2010-2012 yılları arasının çocuk edebiyatına yönelik tezler açısından oldukça hareketli bir dönem olduğu söylenebilir. Uluslararası tezlere bakıldığında da yine 20102013 yıllarının tez sayısının açısından öne çıktığı; 2014 ve 2017 yıllarında ise dikkat çekici bir biçimde tez oranlarında azalma olduğu görülmektedir.

Lisansüstü düzey açısından karşılaştırıldığında, çocuk edebiyatı alanında ulusal tezlerde yüksek lisans çalışmaları, uluslararası tezlerde ise doktora çalışmaları ön plandadır. Ülkemizde Yükseköğretim Bilgi Yönetim Sistemi’ne bakıldığında, yüksek lisans öğrenci sayıs1 394.174 iken doktora öğrenci sayıs1 96.199'dur (yok.gov.tr, 2019). Yüksek lisans öğrencisinin, doktora öğrenci sayısının yaklaşık 4 katı olması, ulusal 
tezlerdeki yüksek lisans çalışmalarının baskınlığını destekler niteliktedir. Ancak uluslararası tezlere bakıldığında ise doktora çalışmalarının ağırlıklı olduğu görülmekte ve bu durum, birçok ana bilim dalındaki programlarda çocuk edebiyatı çalışmalarının yürütülmesi ile açıklanabilir: Edebiyat, Düşünce ve Kültür, Dil ve Okuryazarlık, İngiliz Dili ve Edebiyatı, Eğitim Bilimleri Ana Bilim Dalları yani Okul Öncesi, İlköğretim, Dil Becerileri, Öğretim Programı ve Öğretim gibi birçok ana bilim dalında çocuk edebiyatına yer verilmesi, bu alandaki tez sayısını olumlu yönde etkileyebilir. Ayrıca yurtdışında doktora programının iki yönlü olması (EdD ve $\mathrm{PhD})$ da etkili olabilir. Yine de lisansüstü düzey arasındaki fark üzerinde başka değişkenler de göz önüne alınmalıdır: çocuk edebiyatı alanına daha çok doktora düzeyinde yönelme, yapılan tezlerin kapsamının doktora düzeyini karşılar nitelikte olabileceğini düşünme, vb.

Araştırma deseni açısından ulusal ve uluslararası tezlere bakıldı̆̆ında ise en çok nitel araştırma yaklaşımının; nitel araştırmalar içinde ise en çok içerik analizinin benimsendiği belirlenmiştir. Şahin, Kana ve Varışoğlu (2013), Ertekin ve Çamlıbel Çakmak (2019) ile Balta'nın (2019) çalışmasında da nitel araştırmaların öne çıkığ belirlenmiştir. Yine Boyacı ve Demirkol'un (2018) çalışmasında \%39 oranıyla en çok nitel araştırmaların kullanıldığı belirtilmektedir. Bu açıdan ulusal tezlerde ulaşılan sonuçlarla benzerlik göstermektedir. Hsu (2005) ile Demir ve Koçyiğit (2018), uluslararası alanyazında nicel araştırmalardan nitele doğru bir araştırma eğilimi olduğu ve nitel araştırmaların en çok benimsendiği sonucuna ulaşmıştır. Uluslararası tezlerdeki nitel araştırma eğilimini destekler niteliktedir.

Karma desenin ise uluslararası tezlerde ulusal tezlere oranla daha çok ele alındığı görülmektedir. Ulusal tezlerde oran \%15 iken uluslararası tezlerde \%25'tir. Sözbilir, Kutu ve Yaşar (2012), Türkiye'deki bilim eğitimi araştırmasındaki eğilimi belirlemek amacıyla çalışmasında ele aldığı 1249 araştırmanın \%66.8'inin nicel, \%30'unun nitel, \%3.2'sinin ise karma desen olduğunu belirlemiştir. Ancak karma desen içerisinde nitel ve nicel araştırma desen tasarımını ele almış; bu bağlamda bu araştırmada ulaşılan \%6.36 oranıly karşılaştırıldığında Türkiye'de hâlâ karma araştırma desenine pek yer verilmediği söylenebilir. Ayrıca aynı araştırmada Türkiye'deki veri toplama araçları da ele alınmış; ikiden fazla veri toplama aracını işe koşan araştırmaların az sayıda olduğu sonucuna ulaşılmıştır. Aynı durum, çocuk edebiyatı bağlamında ele alınan ulusal tezler için de geçerlidir. Yalnızca 7 tezde üç veri toplama aracının işe koşulduğu belirlenmiştir. Uluslararası tezlere bakıldığında ise karma araştırma yöntemlerine olan eğilimin daha çok yansıdığ 1 , incelenen tezlerin 1/4'ünün karma araştırma desenini benimsediği belirlenmiştir. Ayrıca karma desende genellikle üç olmak üzere veri toplama aracı 6'ya kadar çıkan araştırmalarla (f:2) karşılaşılmıştır. Truscott, vd. (2010), 1995-2005 yılları arasında önde gelen 11 uluslararası İngilizce ve ABD ulusal eğitim araştırma dergisinde yayımlanan karma yöntem araştırmalarının yaygınlığını incelemiş ve 2381 çalışmanın (okuma yazma, matematik, sosyal bilgiler ve fen alanları) 332'sinde (\%14) karma yöntem kullanıldığ belirlenmiştir. Uluslararası tezlerde nitel ve nicel araştırma desen tasarımında \%11'lik bir orana ulaşılmış ve bu açıdan sonuçlar benzerlik göstermektedir. Yine Ross ve Onwuegbuzie'nin (2010) çalışmasında 1998-2008 yılları arasında karma araştırmaların dergilerin \%33'ünü oluşturduğu ve bu araştırmaların yaklaşık yarısının nitel eğilimli 
olduğuna ulaşılmıştır. Uluslararası tezlerde de nitel temelli karma araştırmaların \%11.49 oranıyla yaklaşık yarısını oluşturması, uluslararası alanyazında nitel yönde karma araştırma tasarımlarının da yeğlendiğini göstermektedir.

Veri toplama aracı açısından bakıldığında ise hem ulusal hem de uluslararası tezlerde, en çok içerik analizi kullanılmış, bunu görüşme ve anket izlemektedir. Ulusal tezlerde veri toplama araçlarından yalnızca anket kullanım oranı uluslararası tezlerden fazladır. Doküman analizi, görüşme ve anket kullanım sıklığı, alanyazındaki birçok çalışmada da belirlenmiştir (Varışoğlu, Şahin ve Göktaş, 2013; Çam Aktaş, 2016; Biçer, 2017; Dündar ve Hareket, 2017; Erdem, 2018; Türkben, 2018; Balta, 2019; Veyis, 2020). Dolayısıyla veri toplama araçlarının ağırlıklı olarak doküman analizi ya da anket çerçevesinde biçimlenmesi, ulusal çalışmalarda daha çok yönlü veri toplama aracına gereksinim duyulduğunu ortaya çıkarmaktadır. Uluslararası tezlerde, her ne kadar doküman analizi öne çıksa da farklı veri toplama araçlarıyla ilişkilendiren çalışmaların sayısı azımsanmayacak niteliktedir (f:39). Bu nedenle ulusal çalışmalarda veri toplama araçları yönünden çeşitliliğe gereksinim duyulmaktadır.

Ulusal ve uluslararası tezlerin evren/örneklem ya da çalışma grubuna bakıldığında, en çok basılı materyaller üzerinde çalışıldığı; her ikisinde öğretmenlerle yapılan çalışmalar benzer orandayken öğretmen adayları ile yapılan çalışmalarda uluslararası tezler öne çıktığı belirlenmiştir. Göktaş, vd.'nin (2012) çalışmasında da çalışma grubu olarak en çok öğretmen adayı ve öğretmenler olduğu belirlenmiştir. Ancak uluslararası tezlere bakıldığında, farklı çalışma grupları (psikolog, haham ve sosyal hizmet uzmanı, yazar, çizer, eleştirmen ve yayınevi sahipleri, veliler, okul müdürleri ve danışmanlar, blog, sergi, medya ve okuma uzmanı, vb.) ile çalışıldığ görülmektedir.

Konu dağılımı açısından ulusal tezlerde en çok çocuk edebiyatının eğitimdeki işlevine, uluslararası tezlerde ise en çok çocuk edebiyatına ideolojinin yansımalarına yer verilmiştir. Balta (2019), odak noktası çocuk edebiyatı olan tezlerin konularının ağırlıklı olarak eğiticilik/eğitsel ileti olduğunu belirtmiştir. Balcı (2012) çalışmasında, çocuk edebiyatı ürünlerinde edebi (yazınsal) türler konusunu en çok çalışılan konu olarak belirlemiş, yıllara göre çocuk edebiyatı ve Türkçe eğitimi konusundaki artışa dikkat çekmiştir. Bu çalışmanın bulguları da çocuk edebiyatının genelde eğitim ve özelde Türkçe eğitimi ile ilişkili tez çalışmalarının sürdüğünü göstermektedir. Ayrıca Yazıcı (2013), belirli bir yapıtı ya da bir yazarın birden fazla yapıtını ele alarak buradaki belirli bir izleğin (tema), iletinin, eğitsel işlevin izini arayan tezlerin çocuk edebiyatı alanındaki akademik çalışmaların ağırlık noktasını oluşturduğunu belirtmektedir.

Çocuk edebiyatında ileti, çocuk edebiyatında izlek (tema), çocuk edebiyatını zayıflatan ögeler, farklı ülkelerdeki çocuk edebiyatı, çocuk edebiyatına kuramsal yaklaşım, çocuk edebiyatı ve drama, ulusal tezlerde yer alan konulardır. Çocuk edebiyatı ve çocuk kütüphanesi, çocuk edebiyatı ve kültürel aktarım/yansıma, çocuk edebiyatı ve toplum gerçekliği, sosyoloji, çocuk edebiyatı ve oyun, çocuk edebiyatı ve müze, çocuk edebiyatı ögelerinden mekân, çocuk edebiyatı ve kitapların niteliği, çocuk edebiyatı ve yetişkin edebiyatı arasındaki ilişki, çocuk edebiyatı ögelerinden zaman, çocuk edebiyatı ve dinsel yansıma, çocuk edebiyatı ve cinsellik, çocuk edebiyatı ve çocuk dünyası, çocuk edebiyatı ve okur, çocuk edebiyatı ve mizah, çocuk edebiyatı ve çevre bilinci, uluslararası tezlerde 
yer alan konulardır. Uluslararası konuların çeşitliliği ön plana çıkmaktadır. İdeoloji ile ilgili çalışmalarda ulusal tezlerde çocuk hakları, siyaset ve cinsiyetçilik ele alınırken uluslararası tezlerde bu konu alanındaki çeşitlilik dikkat çekmektedir: siyaset, feminizm ve kadın imgesi, cinsiyet rolleri ve algısı, ayrımcılık ve cinsiyet ayrımcılı̆̆ 1 , 1 rkçılık, yasaklanan kitaplar, cumhuriyetçilik, faşizm ve ulusalcılık. Ayrıca uluslararası tezlerde öne çıkan ve ulusal tezlerde ele alınmayan birçok konu da öne çıkmaktadır: çokkültürlülük, yerel ve melez kültür karşılaştırmaları, eşcinsellik, sosyal sınıf ve mitler...

Uluslararası tezlerde bu konuların ele alınmasında, toplumsal gerçeklik önemli rol oynamaktadır. Örneğin; 1965 yılında Çocuklar için Irklar Arası Kitaplar Konseyi (The Council on Interracial Books for Children) kurulmuş ve 1960 yılında başlatılan İnsan Hakları Hareketi'nin bir uzantısı olarak bu konsey, çok ırklı toplumu yansıtacak çocuk edebiyatının geliştirilmesinde rol oynamaktadır. Ayrıca çocuk edebiyatındaki ırkçılık ve cinsiyetçilik konularını ele almasının yanı sıra başta Afrikalı Amerikalılar olmak üzere Asyalılar, Latinler, Yerli Amerikalılar ve kadınların çocuk edebiyatında ele alınışını incelemektedir (Banfield, 1998). Dolayısıyla çok 1rklı, çok kültürlü toplumsal yaşamın gereği, bu tür konular baskın olarak ele alınmaktadır. Bu baskınlık konular içerisinde karakterlerin ele alınmasına da yansımıştır. Uluslararası tezlerde karakterler farklı yönleriyle incelenmiştir: erkek, kadın ve çocuk; yetim, kötü, engelli ve kurtarıcı (kahraman) karakterler, ikincil (yardımcı) karakterler, prenses karakteri, çılgın bilim adamı karakteri vb. Ulusal tezlerde karakterler üzerine çalışmalar yüzeysel kalmıştır. Dolayısıyla ulusal tezlerde çocuklar için yazılan yapıtların "hangi gerçeklik"lere dayanılarak yapılandırıldığı ve hangi gerçeklikler üzerinden bir çocukluk politikası geliştirildiği sorusu, ele alınması gereken önemli sorular arasındadır. Ulusal tezlerin gerek konu, gerekse araştırma aşamaları yönünden uluslararası tezlerin incelenerek yapılandırılması, alanyazın açısından önem taşımaktadır.

\section{Sonuç}

Ulusal tezlerdeki çalışma konularına bakıldığında, tezlerin aynı döngü içinde ilerlediği, çocuk edebiyatına kuramsal olarak yaklaşıldığı görülmektedir. Çocuk edebiyatının ilkeleri, ögeleri, gelişimi ele alınmaktadır. Ancak çocuğu bir birey olarak değerlendirmek, çocuk dünyasını tanımak, çocuğun gereksinimlerini bilmek, çocuk karakterlerde gelişim dönemlerinin etkisini araştırmak gerekmektedir. Çocuğun doğasında olan merak ve bununla gelişen yaratıcılık üzerinde çalışılmaması da bir eksiklik olarak değerlendirilebilir. Çocuk edebiyatına özgü özellikler, çocuk edebiyatı temel ilkeleri, çocuğa görelik, çocuk gerçekliği ile sınırlandırılmayarak çocukluk kavramı, çocuk imgesi ve yaratıcılık üzerinde de durulmalıdır. Çocuğun karakterlerle özdeşim kurduğu göz önünde bulundurularak karakterle ilgili çalışmaların arttırılması ve daha derinlemesine çalışılması gerekmektedir. Bu nedenle çocuk edebiyatına ilişkin hazırlanacak tezlerde konu çeşitliliğinin arttırılması önemlidir.

Çocuk edebiyatında yapılacak tezlerde nitel araştırma yöntemlerinin yanı sıra karma araştırma yöntemine de eğilim gösterilmesi; araştırma deseninin ve yönteminin belirtilmesi, veri toplama araçlarının verilmesi ve özetlerde gereken bilgilerin bulunması da öne çıkan öneriler arasındadır. Bunları yapabilmenin yolu, tez yazım kurallarını 
uygulamak ve doğru biçimde uygulatmaktan geçmektedir. Tez yazım kılavuzları, bilimsel çalışmalarda yer alması gerekenleri belirterek belli bir düzen içinde yapılmasını sağlamak için hazırlanmaktadır. Tezlerdeki biçim, içerikle ilgili farklılıklar göz önünde bulundurulduğunda, bu kılavuzların anlaşılır, tüm üniversitelerce kabul edilebilir, işlevsel duruma getirilmesi gerekmektedir.

\section{Kaynaklar}

Akaydın, Ş. \& Çeçen, M. A. (2015). A content analysis on articles related to reading skills. Education and Science, 40(178), 183-198. http://dx.doi.org/10.15390/EB.2015.4139

Aktaş, E. \& Uzuner Yurt, S. (2015). A content analysis for article abstracts in Turkish education area. Turkish Studies, 10(7), 73-96. http://dx.doi.org/10.7827/TurkishStudies.8121

Alpkıray, F. \& Samur, Y. (2017). A content analysis of thesis and dissertations published in Turkey on electronic books. SDU International Journal of Educational Studies, 4(1), 12 28.

Altunya, H. (2012). Türk çocuk edebiyatı kaynakçası [Turkish children's literature bibliography]. Ankara: Ankara Üniversitesi Basımevi.

Alver, M. \& Taştemir, L. (2017). Examination of Postgraduate Thesis on Speaking Skills. International Journal of Languages' Education and Teaching, 5(3), 451-462. http://dx.doi.org/10.18298/ijlet.2041

Baki, A. \& Gökçek, T. (2012). A general overview of mixed method researches. Elektronik Sosyal Bilimler Dergisi, 11(42), 1-21. Retrieved from https://dergipark.org.tr/en/pub/esosder/issue/6156/82721

Balcı, A. (2012). Türkiye'de çocuk edebiyatı üzerine hazırlanan lisansüstü tezler hakkında bir meta-analiz çalışması [A meta-analysis study on post-graduate theses written on children's literature in Turkey]. Mustafa Kemal University Journal of Graduate School of Social Sciences, 9(17), 195-206. Retrieved from https://dergipark.org.tr/tr/pub/mkusbed/issue/19553/208286

Balta, E. E. (2019). Çocuk edebiyatı üzerine yapılmış lisansüstü çalışmaların içerik analizi (20112018 y1llar1) [A content analysis post-graduate studies in Turkey about children's literature (2011-2018 period)]. OPUS Uluslararası Toplum Araştırmaları Dergisi, 10(17), 464-489. Retrieved from https://dergipark.org.tr/tr/pub/opus/issue/42322/510809

Banfield, B. (1998). Commitment to change: the council on interracial books for children and the world of children's books. African American Review, 32 (1), 17-22. Retrieved from https://eric.ed.gov/?id=EJ566984

Biçer, N. (2017). Yabancılara Türkçe öğretimi alanında yayınlanan makaleler üzerine bir analiz çalışması [An Analysis Study on the Published Articles Relating to the Field of Teaching Turkish to Foreigners]. Pamukkale Üniversitesi Sosyal Bilimler Enstitüsü Dergisi, 27, 236247. http://dx.doi.org/10.5505/pausbed.2017.69772

Boyacı, S. \& Demirkol, S. (2018). Türkçe eğitimi alanında yapılan doktora tezlerinin incelenmesi [An examination of doctoral dissertations in the field of teaching Turkish]. Ana Dili Eğitimi Dergisi, 6(2), 512-531. https://doi.org/10.16916/aded.363599

Bozkurt, B. Ü. \& Uzun, N. E. (2015). Türkçenin eğitimi-öğretimine ilişkin bir alanyazını değerlendirmesi: uluslararası bilimsel toplantılarda eğilimler/yönelimler [A review of literature on Turkish language education: trends in international conferences]. Journal of Language Education and Research, 1(2), 1-15. Retrieved from https://dergipark.org.tr/tr/pub/jlere/issue/18968/200358?publisher=jlere 
Büyükikiz, K. (2014). Yabancılara Türkçe öğretimi alanında hazırlanan lisansüstü tezler üzerine bir inceleme [An investigation on graduate dissertations written on Turkish teaching as a foreign language]. Mustafa Kemal University Journal of Graduate School of Social Sciences, 11(25), 203-213. Retrieved from https://dergipark.org.tr/en/download/articlefile/183334

Büyüköztürk, Ş., Çakmak, E. K., Akgün, Ö. E., Karadeniz, Ş. \& Demirel, F. (2009). Bilimsel araştırma yöntemleri [Scientific research methods]. (5th ed.). Ankara: Pegem A Yayınc1lik.

Ceran, D., Aydın, M. \& Onarıcıŏlu, A. S. (2018). Okuma eğitimi üzerine yapılan tezlerde eğilimler: bir içerik analizi çalışması [Trends in theses on reading education: a content analysis study]. Ahi Evran Üniversitesi Kırşehir Eğitim Fakültesi Dergisi (KEFAD), 19(3), 2377-2392. http://dx.doi.org/10.29299/kefad.2018.19.03.016

Coşkun, E., Özçakmak, H. \& Balc1, A. (2012). Türkçe eğitiminde eğilimler: 1981- 2010 yılları arasında yapılan tezler üzerine bir meta-analiz çalışması [Trends in Turkish education: A meta-analysis study on theses conducted between 1981-2010]. In E. Y1lmaz, M. Gedizli, E. Özcan and Y. Koçmar, (Ed.), Türkçenin Eğitimi Öğretimi Üzerine Çalı̧̧malar (pp. 204212). Ankara: Pegem Akademi Yayıncılık.

Çam Aktaş, B. (2015-2016). Türkiye'de eleştirel okuma kapsamında gerçekleştirilen çalışmaların incelenmesi [An evaluation of researches done on critical reading in Turkey]. Akademik Araştırmalar Dergisi, 17(67- Türkçe Öğretimi Özel Sayıs1), 217-232. Retrieved from https://earsiv.anadolu.edu.tr/xmlui/bitstream/handle/11421/14861/14861.pdf?sequence=1

Değirmenci Gündoğmuş, H. (2018). Okuduğunu anlama ile ilgili yapılan lisansüstü tezlerin incelenmesi [The analysis of the graduate thesis related to reading comprehension]. Turkish Studies, 13(3), 899-910. http://dx.doi.org/10.7827/TurkishStudies.13218

Demir, Y. \& Koçyiğit, M. (2018). A Systematic Review of Research on English Language Teacher Education Published in Three Flagship Journals (1997-2016). EKUAD [JETPR], 4(1), 128138. Retrieved from http://ekuad.com/articles/a-systematic-review-of-research-on-englishlanguage-teacher-education-published-in-three-flagship-journals-1997-2016.pdf

Demircan, C. (2007). Çocuk edebiyatı konulu lisansüstü çalışmalar ile ilgili bir durum araştırması [A case study on graduate studies about children's literature]. Sakarya Üniversitesi Eğitim Fakültesi Dergisi, 13, 23-35. Retrieved from https://dergipark.org.tr/tr/pub/sakaefd/issue/11226/134022

Dilidüzgün, S. (2003). Illetişim odaklı Türkçe derslerinde çocuk kitapları [Children's books in communication-oriented Turkish lessons]. İstanbul: Morpa Yayını.

Dilidüzgün, S. (2004). Çağdaş çocuk yazını kitapları [Contemporary children's literature books]. İstanbul: Morpa Yayınları.

Dilşad Ertekin, B. \& Çamlıbel Çakmak, Ö. (2019). Okulöncesi eğitim literatüründeki resimli çocuk kitaplarına yönelik yapılan lisansüstü tezlerin incelenmesi [An overview of postgraduate theses within the field of illustation children books at early childhood education]. Journal of Social and Humanities Sciences Research, 6(40), 2111-2124. Retrieved from http://www.jshsr.org/Makaleler/1659868954_18_2019_640.ID1324.\%20ERTEK\%c4\%b0N\&\%c3\%87AKMAK-\%202111-2124.pdf

Doğan, Y. \& Özçakmak, H. (2014). Dinleme becerisinin eğitimi üzerine yapılan lisansüstü tezlerin değerlendirilmesi [Evaluation of the graduate theses performed on listening skills' education]. Journal of Mother Tongue Education, 2(2), 90-99. https://doi.org/10.16916/aded.46766

Erdem, C. (2018). Medya okuryazarlığı araştırmalarında eğilimler: lisansüstü tezlere yönelik bir içerik analizi [Trends in media literacy research: a content analysis of postgraduate 
dissertations]. Journal of Theoretical Educational Science, 11(4), 693-717. http://dx.doi.org/10.30831/akukeg.390260

Eski, B. (2019). Türkiye'de dramayla dil eğitimi alanında yapılan lisansüstü araştırmaların eğilimleri [Tendencies of postgraduate researches in the field of language education by creative drama]. Social Sciences: Theory \& Practice, 3(2), 53-64. Retrieved from https://dergipark.org.tr/tr/download/article-file/910468

Fidan, M. (2019). Çocuk edebiyatı eserlerini değerler eğitimi yönünden inceleyen lisansüstü tezlerin analizi [Analysis of postgraduate theses examining children's literature works in terms of values education]. In M. B. Minaz \& M. Sert A ğır (Ed.), Eğitim Bilimleri Alaninda Araştırma Makaleleri (pp.231-246). Ankara: Gece Akademi.

Göktaş, Y., Hasançebi, F., Varışoğlu, B., Akçay, A., Bayrak, N., Baran, M. \& Sözbilir, M. (2012). Trends in educational research in Turkey: a content analysis. Educational Sciences: Theory \& Practice, 12(1), 455-460. Retrieved from https://files.eric.ed.gov/fulltext/EJ978453.pdf

Hsu, T. (2005). Research methods and data analysis procedures used by educational researchers, International Journal of Research and Method in Education, 28(2), 109-133. http://dx.doi.org/10.1080/01406720500256194

Hunt, P. (2005). Introduction: the expanding world of children's literature studies. In P.Hunt (Ed.), Understanding Children's Literature (pp.1-14). London: Routledge.

Kantarcioğlu, S. (1991). Eğitimde masalın yeri [The importance of fairy tales in education]. Ankara: Millî Eğitim Bakanlığı Yayınları- Öğretmen Kitabı Dizisi.

Karakaya, İ. (2014). Bilimsel araştırma yöntemleri [Scientific research methods]. In A.Tanrı̈ğen, (Ed.), Bilimsel Araştırma Yöntemleri [Scientific research methods] (pp.55-84). Ankara: Anı Yayınc1l1k.

Kurt, A. \& Erdoğan, M. (2015). Program değerlendirme araştırmalarının içerik analizi ve eğilimleri; 2004-2013 yılları arası [Content Analysis and Trends of Curriculum Evaluation Research: 2004- 2013]. Education and Science, 40(178), 199-224. http://dx.doi.org/10.15390/EB.2015.4167

Küçük, S. \& Kaya, E. (2018). Yabancı dil olarak Türkçe öğretimi ile ilgili hazırlanan tezlerde geçen anahtar kelimelere yönelik içerik analizi [Content analysis of the keywords in the dissertations on teaching Turkish as a foreign language]. Journal of History Culture and Art Research, 7(5), 442456. http://dx.doi.org/10.7596/taksad.v7i5.1880

Lynch-Brown, C. \& Tomlinson, C. M. (1999). Essentials of children's literature. (3th Ed.). Needham, Massachusetts: Allyn and Bacon.

Neydim, N. (2003). Çocuk edebiyatı [Children's literature]. İstanbul: Bu Yayınevi.

Özdemir, S. (2018). Okumaya ilişkin lisansüstü araştırmaların eğilimleri [Research Trends in Postgraduate Studies on Reading]. Journal of Mother Tongue Education, 6(4), 1161-1178. https://doi.org/10.16916/aded.455560

Potur, Ö. \& Yıldız, N. (2016). Konuşma becerisi alanında yapılan akademik çalışmaların eğilimleri [Tendencies of academic studies in speaking skills field]. Journal of Language and Literature Education, 18, 27-40.

Sever, S. (2003). Çocuk ve edebiyat [Child and literature]. Ankara: Kök Yayıncılık.

Sevim, O. \& İşcan, A. (2012). Türkçenin eğitimi ve öğretimi alanında yapılan yüksek lisans tezlerinde geçen anahtar kelimelere dönük bir içerik analizi [A content analysis of keyword of theses in the field of Turkish education and teaching]. Turkish Studies, 7(1), 1863- 1873. http://dx.doi.org/10.7827/TurkishStudies.3101

Sevim, O. \& Özdemir Erem, N. H. (2012). Türkçe eğitimi alanındaki yüksek lisans tezlerinin başlıklarına ve özetlerine eleştirel bir bakış [A critical evaluation to abstracts and titles of 
master thesis in Turkish language education]. TEKE [International Journal of Turkish Literature Culture Education], 1 (3), 174-186.

Sözbilir, M., Kutu, H. \& Yaşar, M. D. (2012). Science education research in Turkey: A content analysis of selected features of papers published. In J. Dillon\& D. Jorde (Eds), The World of Science Education: Handbook of Research in Europe (pp.341-374). Rotterdam: Sense Publishers.

Şahin, E. Y., Kana, F. \& Varışoğlu, B. (2013). Türkçe eğitimi bölümlerinde yapılan lisansüstü tezlerin araştırma eğilimleri [The research trends of postgraduate dissertations in Turkish education departments]. International Journal Of Human Sciences, 10(2), 356- 378.

Şeref, İ. (2019). Türkçe öğretiminde şiir üzerine yapılan lisansüstü tezlerin değerlendirilmesi [An evaluation of postgraduate theses on poetry in Turkish teaching]. I $\breve{g} d \imath$ Üniversitesi Sosyal Bilimler Dergisi, 20, 335-349.

Şirin, M. R. (Ed.). (2000). 99 soruda çocuk edebiyatı [Children's literature in 99 questions] (3th ed.). İstanbul: Çocuk Vakfı Yayınları.

Tanrıverdi, B. \& Apak, Ö. (2013). Görsel okuryazarlık üzerine bir içerik analizi [A content analysis on visual literacy]. Uludă̆ Üniversitesi Ĕgitim Fakültesi Dergisi, 26 (1), 267-293. Retrieved from https://dergipark.org.tr/tr/download/article-file/153503

Tok, M. \& Potur, Ö. (2015). Yazma eğitimi alanında yapılan akademik çalışmaların eğilimleri (2010-2014 y1llar1) [Trends of the academic studies in writing education area (2010 - 2014 years)]. Ana Dili Eğitimi Dergisi, 3(4), 1-25. Retrieved from http://www.anadiliegitimi.com/en/download/article-file/14934

Truscott, D.M., Swars, S., Smith, S., Thornton-Reid, F., Zhao, Y., Dooley, C., Williams, B., Hart, L. \& Matthews, M. (2010). A cross-disciplinary examination of the prevalence of mixed methods in educational research: 1995-2005. International Journal of Social Research Methodology, 13 (4), pp.317-328 https://doi.org/10.1080/13645570903097950

Turan, L., Sevim, O. \& Tunagür, M. (2018). Türkçe eğitimi alanındaki doktora tezlerinin özet bölümlerine yönelik bir içerik analizi [A content analysis for the summary sections of doctoral theses in the field of Turkish education]. Uluslararası Türk Eğitim Bilimleri Dergisi, 11, 29-44. Retrieved from https://dergipark.org.tr/tr/download/article-file/554688

Türkben, T. (2018). Yabancı dil olarak Türkçe öğretimi alanında yapılan lisansüstü çalışmaların değerlendirilmesi [Evaluation of postgraduate studies conducted on teaching Turkish as a foreign language]. TEKE [International Journal of Turkish Literature Culture Education], 7(4), 2464-2479. Retrieved from https://dergipark.org.tr/tr/download/article-file/623535

Varışoğlu, B., Şahin, A. \& Göktaş, Y. (2013). Türkçe eğitimi araştırmalarında eğilimler [Trends in Turkish education studies]. Kuram ve Uygulamada Eğitim Bilimleri [Educational Sciences:Theory and Practice], 13 (3), 1767- 1781.

Veyis, F. (2020). Türk dili ve edebiyatı eğitimi alanında lisansüstü araştırmalar üzerine bir inceleme [An investigation on graduate research in Turkish language and literature education]. Atatürk Üniversitesi Türkiyat Araştırmaları Enstitüsü Dergisi, 67, 683-702. https://doi.org/10.14222/Turkiyat4284

Yazıcı, N. (2013). Çocuk edebiyatı alanında üniversitelerde yapılan lisans sonrası çalışmalar [An analysis on the graduate studies on children's literature in universities]. Hacettepe Üniversitesi Eğitim Fakültesi Dergisi [H. U. Journal of Education], 28 (1), 441-452, Ankara. Retrieved from https://dergipark.org.tr/en/download/article-file/87153

Yıldırım, A. \& Şimşek, H. (2006). Sosyal bilimlerde nitel araştırma yöntemleri [Qualitative research methods in the social sciences]. (5th ed.). Ankara: Seçkin Yayıncılık.

Yıldız, M., Çoban Süral, Ü. \& Boz, İ. (2019). Türkiye'de okuduğunu anlamayı geliştirmeye dönük ilkokul düzeyindeki çalışmaların sistematik incelenmesi [Systematic review of the studies 
on improving reading comprehension in the primary school level in Turkey]. GEFAD / GUJGEF, 39(2), 1049-1086. https://doi.org/10.17152/gefad.548457

Yıldız, S. (2018). Türkiye'de kadın akademisyen olmak [Being a female academician in Turkey]. Journal of Higher Education and Science, 8(1), 29-40. https://doi.org/10.5961/jhes.2018.245 